\title{
5,7,8-Trimethyl-benzopyran and 5,7,8-Trimethyl-1,4-benzoxazine Aminoamide Derivatives as Novel Antiarrhythmics against Ischemia-Reperfusion Injury
}

\author{
Eftychia N. Koini, ${ }^{\dagger}$ Panagiota Papazafiri, ${ }^{*}$ Athanasios Vassilopoulos, ${ }^{\perp, \ddagger}$ Maria Koufaki, ${ }^{\dagger}$ Zoltán Horváth, ${ }^{\text {I }}$ István Koncz, ${ }^{\S}$ \\ László Virág, ${ }^{\S}$ Gy J. Papp, ${ }^{\S, \| l}$ Andràs Varró, ${ }^{\S, I}$ and Theodora Calogeropoulou* ${ }^{* \dagger}$ \\ Institute of Organic and Pharmaceutical Chemistry, National Hellenic Research Foundation, 48 Vas. Constantinou Avenue, 11635 Athens, Greece, \\ Department of Animal and Human Physiology, School of Biology, University of Athens, Panepistimiopolis, 15784 Athens, Greece, Department of \\ Pharmacology and Pharmacotherapy, University of Szeged, Szeged Dom ter 12 H-6720, Hungary, Research Unit for Cardiovascular Pharmacology, \\ Hungarian Academy of Sciences, Szeged Hungary
}

Received September 29, 2008

\begin{abstract}
6-Hydroxy-5,7,8-trimethyl-benzopyran derivatives and 5,7,8-trimethyl-1,4-benzoxazine analogues substituted by the lidocaine pharmacophore aminoamide functionality at $\mathrm{C} 4$ or N4, respectively, were synthesized and evaluated against arrhythmias associated with ischemia-reperfusion injury. The antiarrhythmic effect of substitutents at positions $\mathrm{C} 2$ and C6 was examined. Six out of the 11 new derivatives, exhibited arrhythmia scores $1.0-1.3$ versus the control $(4.5 \pm 1.2)$, which was also reflected to the \% premature beats $(0.5-3.9)$, control (13.7 \pm 3.6$)$. Selected compounds were further studied by a conventional microelectrode method. 2-Diethylamino-1-(5,7,8-trimethyl-2-phenyl-2,3-dihydro-benzo[1,4]oxazin-4-yl)-ethanone (50) and the troloxinspired 4-(2-diethylamino-acetyl)-2,5,7,8-tetramethyl-3,4-dihydro-2 $H$-benzo[1,4]oxazine-2-carboxylic acid ethyl ester (62) suppress reperfusion arrhythmias and reduce malondialdehyde (MDA) content, leading to a fast recovery of the heart after ischemia-reperfusion. They exhibit combined class IB and class III antiarrhythmic properties, which constitutes them as promising compounds for further studies because, due to their multichannel "amiodarone like" effect, less proarrhythmic complications can be expected.
\end{abstract}

\section{Introduction}

Acute myocardial ischemia causes highly arrhythmogenic changes in cardiac electrical properties ${ }^{1,2}$ that strongly promote ventricular tachycardias and ventricular fibrillation and lead to a high incidence of sudden death in minutes to hours. ${ }^{2}$ Reperfusion through thrombolysis or percutaneous angioplasty (primary PTCA) is standard treatment in impending acute myocardial infarction. ${ }^{3}$ While early reperfusion of the heart is essential in preventing further tissue damage due to ischemia, reintroduction of blood flow can expedite the death of vulnerable, but still viable, myocardial tissue, by initiating a series of events involving both intracellular and extracellular mechanisms. ${ }^{4,5}$ The first few minutes of reperfusion constitute a critical phase, as lethal tissue injury in addition to that already developed during ischemia may be initiated. The manifestations of reperfusion injury include arrhythmia, reversible contractile dysfunctionmyocardial stunning, endothelial dysfunction, and cell death. Reperfusion injury of the myocardium is a complex phenomenon consisting of several independent etiologies. ${ }^{6}$ The mechanisms proposed to contribute include oxygen free radical formation, calcium overload, neutrophil-mediated myocardial and endothelial injury, progressive decline in microvascular flow to the reperfused myocardium, and depletion of high energy phosphate

\footnotetext{
* To whom correspondence should be addressed. Phone: +30107273833 Fax: +30107273818. E-mail: tcalog@eie.gr.

${ }^{\dagger}$ Institute of Organic and Pharmaceutical Chemistry, National Hellenic Research Foundation.

${ }^{\ddagger}$ Department of Animal and Human Physiology, School of Biology, University of Athens.

${ }^{\S}$ Department of Pharmacology and Pharmacotherapy, University of Szeged.

"Research Unit for Cardiovascular Pharmacology, Hungarian Academy of Sciences.

${ }^{\perp}$ Current address: Genetics of Development, Disease Branch, National Institute of Diabetes, Digestive, Kidney Diseases, National Institutes of Health, Bethesda, Maryland, Maryland 20892.
}

stores. ${ }^{7}$ Electrophysiological balance requires precise control of sarcolemmal ion channels and exchangers, many of which are regulated by phosphatidylinositol(4,5)bisphosphate, which is the immediate precursor of inositol $(1,4,5)$ trisphosphate $\left(\mathrm{IP}_{3}\right)$, a regulator of intracellular $\mathrm{Ca}^{2+}$ signaling and, therefore, a potential contributor to arrhythmogenesis by altering $\mathrm{Ca}^{2+}$ homeostasis. ${ }^{7 \mathrm{~b}}$ Recent studies have shown that both $\alpha_{1}$-adrenoceptor subtypes ( $\alpha_{1 \mathrm{~A}}-\mathrm{AR}$ and $\left.\alpha_{1 \mathrm{~B}}-\mathrm{AR}\right)$ can provide protection from $\mathrm{IP}_{3}$ generation and arrhythmogenesis in early postischemic reperfusion through different mechanisms. ${ }^{7 b, c}$

A variety of compounds have been investigated in different experimental models of myocardial ischemia-reperfusion. ${ }^{8}$ These include oxygen free radical scavengers, antioxidants, calcium-channel blockers, inhibitors of neutrophils, nitric oxide, adenosine-related agents, inhibitors of the renin-angiotensin system, endothelin receptor antagonists, $\mathrm{Na}^{+} / \mathrm{H}^{+}$exchange agents, mitochondrial $K_{\text {ATP }}$ channel openers, and antiapoptotic agents. All of these categories of biologically active agents have been demonstrated to protect from reperfusion injury determined as limitation of infarct size, improved myocardial and endothelial function, and reduced incidence of arrhythmias.

It is now well recognized that arrhythmia is the main manifestation of ischemia and reperfusion myocardial dysfunction. ${ }^{9}$ In particular, reperfusion following a certain period of ischemia induces ventricular arrhythmias, such as ventricular tachycardia and ventricular fibrillation, ${ }^{10}$ which are different from coronary-evoked arrhythmias. ${ }^{11}$ Lidocaine, a $\mathrm{Na}^{+}$channel blocker, is often used as an antiarrhythmic drug in ischemiareperfusion situations. ${ }^{12}$ Besides having antiarrhythmic effects, lidocaine may protect myocardium not only against ischemic but also against reperfusion injury by affecting intracellular concentrations of sodium ${ }^{13,14}$ and calcium ${ }^{15,16}$ during ischemia and reperfusion, by protecting cellular membranes against longchain acylcarnitines ${ }^{17}$ and reactive oxygen species, ${ }^{18}$ and perhaps 


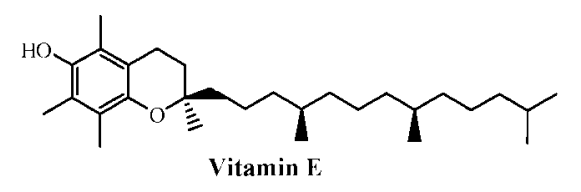

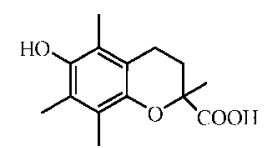

Trolox<smiles>CCN(CC)CC(=O)Nc1c(C)cccc1C</smiles>

Lidocaine

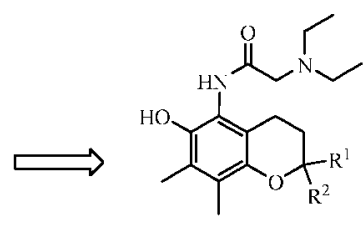

I<smiles>[Y]C1([Y])CC(NC(=O)CN(CC)CC)c2c(C)c(C)c(O)c(C)c2O1</smiles>

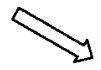

Figure 1. Design of new 5,7,8-trimethylbenzopyran- and 5,7,8-trimethyl-1,4-benzoxazine aminoamide derivatives.

by blocking calcium channels. ${ }^{19,20}$ Lidocaine reduces myocardial ischemia-reperfusion injury in isolated rat heart ${ }^{21,22}$ and in vivo. ${ }^{23-27}$

In our previous studies involving antiarrhythmic antioxidants, ${ }^{28}$ the 6-hydroxy benzopyran ring of vitamin $\mathrm{E}$ and the pharmacophore diethylamino amide moiety of class I antiarrhythmics, procainamide and lidocaine, were combined in a single molecular entity. Among the new analogues, the lidocaine derivatives (I) were the most potent in suppressing reperfusion arrhythmias. As a continuation of our efforts in the field of novel cardioprotective agents against arrhythmias associated with ischemia-reperfusion injury, ${ }^{29}$ we focused our studies on two classes of analogues. The first comprises 6-hydroxy-5,7,8trimethyl-benzopyran derivatives substituted by the lidocaine aminoamide functionality at C-4 (II), while the second encompasses 5,7,8-trimethyl-1,4-benzoxazine analogues in which the lidocaine aminoamide functionality constitutes part of the heterocyclic system (III). In addition, we studied the antiarrhythmic effect of alkyl or aryl substitutents at position C2 as well as of substituents at position C6. (Figure 1). Selected compounds were further studied by a conventional microelectrode method in order to get insight into their cellular mode of action.

\section{Chemistry}

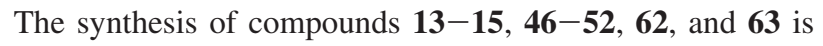
depicted in Schemes 1-5. More specifically, condensation of 3,6-dihydroxy-2,4,5-trimethyl acetophenone with acetone or 2-octanone in the presence of pyrrolidine and molecular sieves in ethanol gave chromanones $\mathbf{1}$ and $\mathbf{2}$, respectively, while condensation of 3,6-dihydroxy-2,4,5-trimethyl acetophenone with benzaldehyde in the presence of piperidine, boric acid, and silica gel in $\mathrm{DMF}^{30}$ afforded 3. Compounds $\mathbf{1}-\mathbf{3}$ upon treatment with hydroxylamine in pyridine were converted to oximes $\mathbf{4 - 6}$, which were in turn reduced to the corresponding amines 7-9 using $\mathrm{TiCl}_{4} / \mathrm{NaBH}_{4}$ in DME. ${ }^{31}$ Analogues 7-9 were acylated using bromoacetyl chloride in the presence of $\mathrm{NaHCO}_{3}$ in THF/ $\mathrm{H}_{2} \mathrm{O}$ to afford bromoamides 10-12, which reacted with diethylamine in toluen $\mathrm{e}^{32}$ to produce the desired 4-aminobenzopyran derivatives 13-15. The preparation of 1,4-benzoxazinone derivatives 20-23, 25, 26, and $\mathbf{3 1}$ is depicted in Schemes 2 and 3. Thus, treatment of 2,3,5-trimethylphenol (16) with $\mathrm{NaNO}_{3}$ in the presence of $\mathrm{HCl}$ and a catalytic amount of $\mathrm{La}\left(\mathrm{NO}_{3}\right)_{3}$ in a biphasic system (water-ether) ${ }^{33}$ gave 2,3,5-trimethyl-6-nitrophenol (17), which was alkylated with the appropriate $\alpha$-bromoester in the presense of $\mathrm{Cs}_{2} \mathrm{CO}_{3}$ and a catalytic amount of TBAI to give ethers 18, 19, and 24. Hydrogenation of $\mathbf{1 8}$ and
19 gave the corresponding anilines, which spontaneously cyclized to benzoxazinones $\mathbf{2 0}$ and $\mathbf{2 1}$, respectively. Reduction of the nitro group in compound $\mathbf{2 4}$ was effected using $\mathrm{CuCl} /$ $\mathrm{NaBH}_{4}$ in ethanol ${ }^{34}$ to give benzoxazinone 25 after spontaneous cyclization. Treatment of $\mathbf{2 0}, \mathbf{2 1}$, and $\mathbf{2 5}$ with a mixture of acetic acid/hydrogen peroxide/hydrogen chloride in petroleum ether afforded the 6-chloro-benzoxazinones $\mathbf{2 2}, \mathbf{2 3}$, and $\mathbf{2 6}$. The synthesis of 2,3,5-trimethyl-6-nitro hydroquinone (27) was effected by hydroxylation of 2,3,5-trimethyl-6-nitro-phenol (17) using $\mathrm{K}_{2} \mathrm{~S}_{2} \mathrm{O}_{8}$ in $10 \%$ aqueous $\mathrm{NaOH}$. Nitration of 2,3,5trimethylhydroquinone afforded the corresponding quinone derivative instead of the 2,3,5-trimethyl-6-nitro hydroquinone. Efforts to nitrate 1,4-dimethoxy-2,3,5-trimethyl phenol resulted in deprotection and oxidation to the quinone, as previously observed. ${ }^{35}$ Protection of the hydroxyl groups of 27 using dimethylsulfate in the presence of $\mathrm{K}_{2} \mathrm{CO}_{3}$ in acetone afforded the dimethoxy derivative $\mathbf{2 8}$, which upon selective deprotection using $\mathrm{BF}_{3} \cdot \mathrm{S}\left(\mathrm{CH}_{3}\right)_{2}{ }^{36}$ complex in $\mathrm{CH}_{2} \mathrm{Cl}_{2}$ yielded 4-methoxy2,3,5-trimethyl-6-nitro-phenol (29). Alkylation with 2-bromo2-phenyl methyl acetate, as above for compound $\mathbf{2 4}$, afforded analogue 30, which upon reduction using $\mathrm{CuCl} / \mathrm{NaBH}_{4}$ in ethanol $^{34}$ and spontaneous cyclization gave benzoxazinone $\mathbf{3 1}$. The final aminoamide derivatives $\mathbf{4 6}-\mathbf{5 2}$ were obtained as described in Scheme 4. Thus, reduction of benzoxazinones 20-23, 25, 26, and 31 with $\mathrm{BF}_{3} \cdot \mathrm{Et}_{2} \mathrm{O}$ and $\mathrm{NaBH}_{4}$ in THF, at $0-5{ }^{\circ} \mathrm{C}$, to the corresponding benzoxazines $\mathbf{3 2}-\mathbf{3 8}$, followed by acylation by bromoacetylbromide in the presense of triethylamine in $\mathrm{CH}_{2} \mathrm{Cl}_{2}$ to give bromoamides $39-\mathbf{4 5}$ and subsequent treatment with diethylamine in toluene produced the final aminoamides $\mathbf{4 6}-\mathbf{5 2}$, respectively. The synthesis of compounds 62 and 63 , which can be envisaged as derivatives of trolox, the water soluble derivative of Vitamin E, was accomplished as depicted in Scheme 5. Alkylation of $\mathbf{1 7}$ using 2-bromo-2-methylmalonic acid diethyl ester to afford $\mathbf{5 3}$ was followed by catalytic hydrogenation to the corresponding aniline, which spontaneously cyclized to benzoxazinone $\mathbf{5 4}$. Treatment of $\mathbf{5 4}$ with a mixture of acetic acid/hydrogen peroxide/hydrogen chloride in petroleum ether afforded the 6-chloro-benzoxazinone 55. The desired benzoxazine derivatives $\mathbf{5 8}$ and $\mathbf{5 9}$ could not be obtained by treatment with $\mathrm{BF}_{3} \cdot \mathrm{Et}_{2} \mathrm{O}$ and $\mathrm{NaBH}_{4}$ or $\mathrm{BH}_{3} \cdot$ THF due to the concomitant reduction of the ester functionality at $\mathrm{C} 2$. We were able to circumvent this problem through formation of the corresponding thioamides $\mathbf{5 6}$ and $\mathbf{5 7}$ by treatment of $\mathbf{5 4}$ and $\mathbf{5 5}$, respectively, with Lawesson reagent ${ }^{37}$ followed by desulphurization using $\mathrm{Ra} / \mathrm{Ni}$ to afford benzoxazines $\mathbf{5 8}$ and $\mathbf{5 9}$, respectively. Acylation by bromoacetylbromide in the presence of triethylamine in $\mathrm{CH}_{2} \mathrm{Cl}_{2}$ gave bromoamides $\mathbf{6 0}$ and $\mathbf{6 1}$, and 
Scheme $1^{a}$

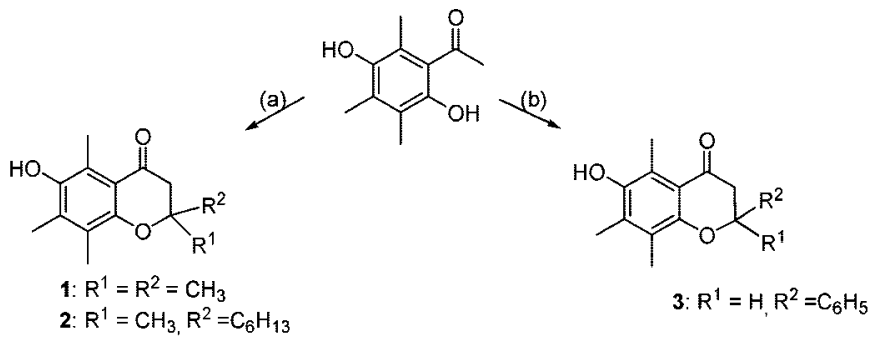

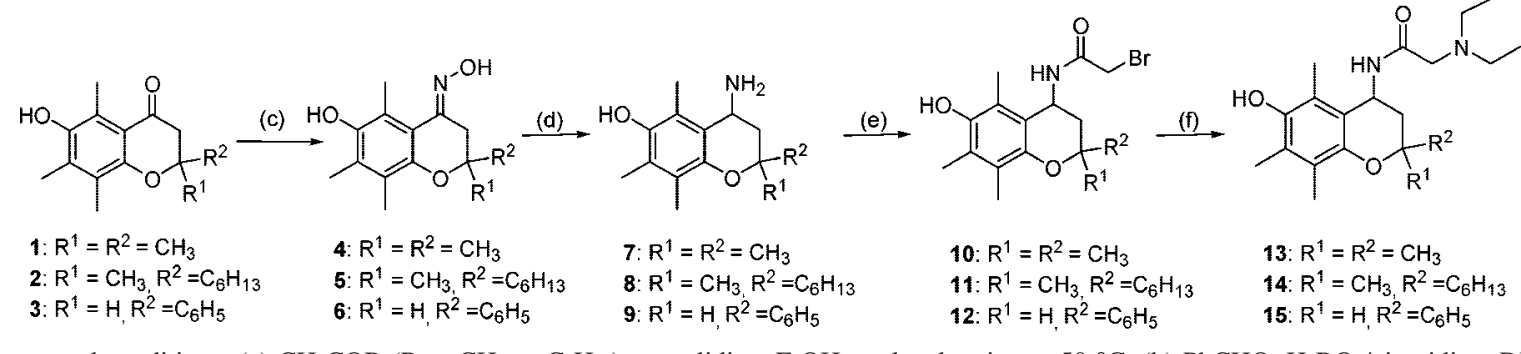

${ }^{a}$ Reagents and conditions: (a) $\mathrm{CH}_{3} \mathrm{COR}\left(\mathrm{R}=\mathrm{CH}_{3}\right.$ or $\mathrm{C}_{6} \mathrm{H}_{13}$ ), pyrrolidine, EtOH, molecular sieves, $50{ }^{\circ} \mathrm{C}$; (b) $\mathrm{PhCHO}, \mathrm{H}_{3} \mathrm{BO} /$ piperidine, DMF, reflux; (c) $\mathrm{NH}_{2} \mathrm{OH} \cdot \mathrm{HCl}$, pyridine, $50{ }^{\circ} \mathrm{C}$; (d) $\mathrm{TiCl}_{4}, \mathrm{NaBH}_{4}, \mathrm{DME}$; (e) bromoacetyl chloride, $\mathrm{NaHCO}_{3}, \mathrm{THF} / \mathrm{H}_{2} \mathrm{O}$; (f) $\mathrm{Et}_{2} \mathrm{NH}$, toluene, $40{ }^{\circ} \mathrm{C}$.

\section{Scheme $2^{a}$}

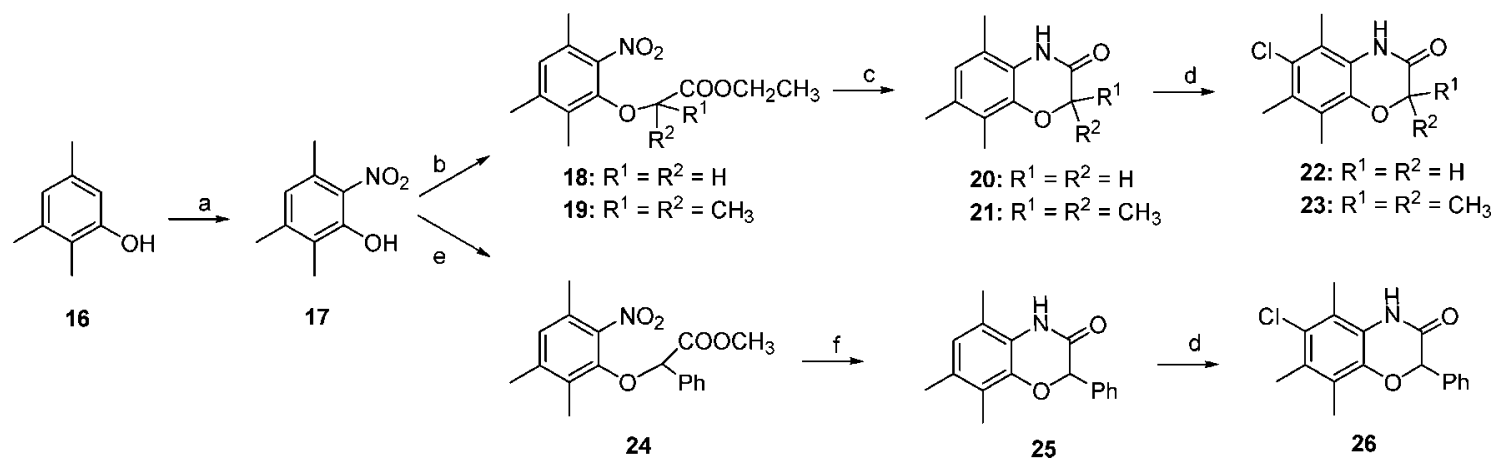

${ }^{a}$ Reagents and conditions: (a) $\mathrm{NaNO}_{3}, \mathrm{La}(\mathrm{NO})_{3}, \mathrm{HCl}, \mathrm{Et}_{2} \mathrm{O}$; (b) $\mathrm{R}^{1} \mathrm{R}^{2} \mathrm{C}(\mathrm{Br}) \mathrm{COOCH}_{2} \mathrm{CH}_{3}, \mathrm{Cs}_{2} \mathrm{CO}_{3}, \mathrm{TBAI}, \mathrm{DMF}, 40{ }^{\circ} \mathrm{C}$; (c) $\mathrm{H}_{2}, \mathrm{Pd} / \mathrm{C}$, EtOH, $50{ }^{\circ} \mathrm{C}$; (d) $\mathrm{AcOH}-\mathrm{H}_{2} \mathrm{O}_{2}-$ conc $\mathrm{HCl}$, PE, reflux; (e) $\mathrm{PhCH}(\mathrm{Br}) \mathrm{COOCH}_{3}, \mathrm{Cs}_{2} \mathrm{CO}_{3}$, TBAI, DMF; (f) $\mathrm{NaBH}_{4}, \mathrm{CuCl}$, EtOH, reflux.

\section{Scheme $3^{a}$}

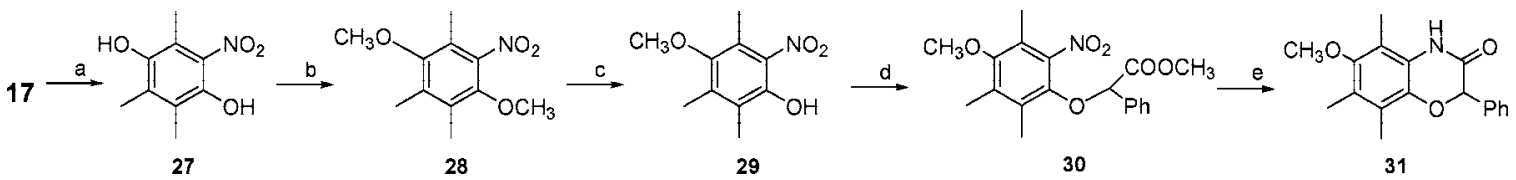

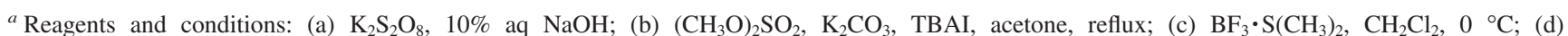
$\mathrm{PhCH}(\mathrm{Br}) \mathrm{COOCH}_{3}, \mathrm{Cs}_{2} \mathrm{CO}_{3}$, TBAI, DMF; (e) $\mathrm{NaBH}_{4}, \mathrm{CuCl}$, EtOH, reflux.

subsequent treatment with diethylamine in toluene produced the final aminoamides 62 and 63 , respectively.

The enantioselective synthesis of $(R)-(-)-1-(6$-chloro-5,7,8trimethyl-2-phenyl-2,3-dihydro-benzo[1,4] oxazin-4-yl)-2-diethylamino-ethanone (51b) is described in Scheme 6. Chlorination of 2,3,5-trimethyl-6-nitrophenol (17) afforded 4-chloro-2,3,5trimethyl-6-nitrophenol (64), which upon Mitsunobu reaction using $(S)-(+)$ - $\alpha$-hydroxy phenyl methyl acetate in the presence of triphenylphosphine and DEAD either at room temperature or at $40{ }^{\circ} \mathrm{C}$ afforded the desired $R$-enantiomer $\mathbf{6 5}$ but in low yield $(\sim 18 \%)$. The yield was dramatically increased when the reaction was performed in an ultrasonic bath $(\sim 75 \%) .{ }^{38}$ The next step was the reduction of the nitro group in $\mathbf{6 5}$ followed by spontaneous cylization to afford $(R)-(-)-6$-chloro-5,7,8trimethyl-2-phenyl-2H-benzoxazine-3(4H)-one (26b). To this end, initially we employed $\mathrm{CuCl}$ in the presence of $\mathrm{NaBH}_{4}$, which afforded benzoxazinone $\mathbf{2 6}$ b but unfortunately as a racemic mixture, or $\mathrm{Ra}-\mathrm{Ni}$, which afforded the desired enantiomer of $\mathbf{2 6 \mathbf { b }}$ but in low yield $(\sim 40 \%)$. We were pleased to find that reduction of $\mathbf{6 5}$ using $\mathrm{Fe}$ in the presence of $\mathrm{NH}_{4} \mathrm{Cl}^{39}$ followed by spontaneous cyclization afforded benzoxazinone $\mathbf{2 6 b}$, in $70 \%$ yield, which upon reduction with $\mathrm{BH}_{3} \cdot \mathrm{SMe}_{2}$ yielded benzoxazine $\mathbf{3 7 b}$. The desired amino amide $\mathbf{5 1 b}$ was obtained after acylation by bromoacetylbromide in the presence of triethylamine in $\mathrm{CH}_{2} \mathrm{Cl}_{2}$ and subsequent treatment with diethylamine in toluene.

\section{Results and Discussion}

The ability of the new analogues $13-15,46-52$, and 62 to suppress reperfusion arrhythmias and to inhibit lipid peroxidation was evaluated using the Krebs perfused Langendorff model $^{40}$ on isolated rat heart preparations (Tables 1 and 2). The results were obtained from 3-5 independent experiments. The compounds were present at the last 5 min of ischemia and during 


\section{Scheme $4^{a}$}<smiles>[X]c1c(C)c(C)c2c(c1C)NC(=O)C([R])([R])O2</smiles>

20: $R^{1}=R^{2}=H, X=H$

21: $R^{1}=R^{2}=\mathrm{CH}_{3}, X=H$

22: $\mathrm{R}^{1}=\mathrm{R}^{2}=\mathrm{H}, \mathrm{X}=\mathrm{Cl}$

23: $\mathrm{R}^{1}=\mathrm{R}^{2}=\mathrm{CH}_{3}, \mathrm{X}=\mathrm{Cl}$

25: $\mathrm{R}^{1}=\mathrm{H}, \mathrm{R}^{2}=\mathrm{C}_{6} \mathrm{H}_{5}, \mathrm{X}=\mathrm{H}$

26: $R^{1}=H, R^{2}=\mathrm{C}_{6} \mathrm{H}_{5}, X=\mathrm{Cl}$

31: $\mathrm{R}^{1}=\mathrm{H}, \mathrm{R}^{2}=\mathrm{C}_{6} \mathrm{H}_{5}, \mathrm{X}=\mathrm{OCH}_{3}$

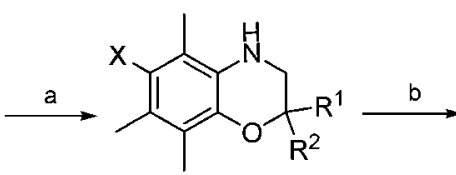

32: $\mathrm{R}^{1}=\mathrm{R}^{2}=\mathrm{H}, \mathrm{X}=\mathrm{H}$

33: $\mathrm{R}^{1}=\mathrm{R}^{2}=\mathrm{CH}_{3}, \mathrm{X}=\mathrm{H}$

34: $R^{1}=R^{2}=\mathrm{H}, X=\mathrm{Cl}$

35: $\mathrm{R}^{1}=\mathrm{R}^{2}=\mathrm{CH}_{3}, \mathrm{X}=\mathrm{C}$ |

36: $\mathrm{R}^{1}=\mathrm{H}, \mathrm{R}^{2}=\mathrm{C}_{6} \mathrm{H}_{5}, X=\mathrm{H}$

37: $\mathrm{R}^{1}=\mathrm{H}, \mathrm{R}^{2}=\mathrm{C}_{6} \mathrm{H}_{5}, X=\mathrm{Cl}$

38: $\mathrm{R}^{1}=\mathrm{H}, \mathrm{R}^{2}=\mathrm{C}_{6} \mathrm{H}_{5}, \mathrm{X}=\mathrm{OCH}_{3}$<smiles>[X]c1c(C)c(C)c2c(c1C)OC([R])([R])CN2C(=O)CBr</smiles>

39: $R^{1}=R^{2}=H, X=H$

40: $\mathrm{R}^{1}=\mathrm{R}^{2}=\mathrm{CH}_{3}, X=\mathrm{H}$

41: $R^{1}=R^{2}=H, X=C \mid$

42: $\mathrm{R}^{1}=\mathrm{R}^{2}=\mathrm{CH}_{3}, \mathrm{X}=\mathrm{Cl}$

43: $\mathrm{R}^{1}=\mathrm{H}, \mathrm{R}^{2}=\mathrm{C}_{6} \mathrm{H}_{5}, \mathrm{X}=\mathrm{H}$

44: $R^{1}=H, R^{2}=\mathrm{C}_{6} \mathrm{H}_{5} X=\mathrm{Cl}$

45: $\mathrm{R}^{1}=\mathrm{H}, \mathrm{R}^{2}=\mathrm{C}_{6} \mathrm{H}_{5}, \mathrm{X}=\mathrm{OCH}$<smiles>[X]c1c(C)c(C)c2c(c1C)OC([R])([R])CN2C(=O)CN(CC)CC</smiles>

46: $R^{1}=R^{2}=H, X=H$

47: $\mathrm{R}^{1}=\mathrm{R}^{2}=\mathrm{CH}_{3}, \mathrm{X}=\mathrm{H}$

48: $R^{1}=R^{2}=\mathrm{H}, X=\mathrm{Cl}$

49: $\mathrm{R}^{1}=\mathrm{R}^{2}=\mathrm{CH}_{3}, \mathrm{X}=\mathrm{Cl}$

50: $R^{1}=H, R^{2}=\mathrm{C}_{6} \mathrm{H}_{5}, X=H$

51: $R^{1}=\mathrm{H}, \mathrm{R}^{2}=\mathrm{C}_{6} \mathrm{H}_{5}, X=\mathrm{Cl}$

52: $R^{1}=H, R^{2}=\mathrm{C}_{6} \mathrm{H}_{5}, X=\mathrm{OCH}_{3}$

${ }^{a}$ Reagents and conditions: (a) $\mathrm{BF}_{3} \cdot \mathrm{Et}_{2} \mathrm{O}, \mathrm{NaBH}_{4}$, THF, $0-5{ }^{\circ} \mathrm{C}$; (b) Bromoacetyl bromide, $\mathrm{Et}_{3} \mathrm{~N}, \mathrm{CH}_{2} \mathrm{Cl}_{2}$; (c) $\mathrm{Et}_{2} \mathrm{NH}$, toluene, $40{ }^{\circ} \mathrm{C}$.

\section{Scheme $5^{a}$}<smiles>CCOC(=O)C(C)(Oc1c(C)cc(C)c([N+](=O)[O-])c1C)C(=O)OCC</smiles><smiles>[X]c1c(C)c(C)c2c(c1C)NC(=S)C(C)(C(=O)OCC)O2</smiles>

54: $\mathrm{X}=\mathrm{H}$

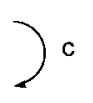

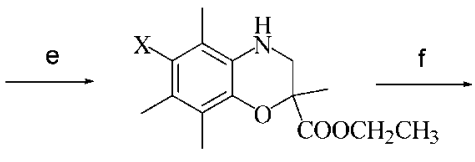

58: $\mathrm{X}=\mathrm{H}$

59: $\mathrm{X}=\mathrm{Cl}$

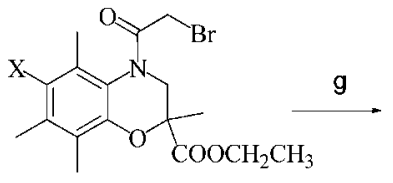

60: $X=H$

61: $\mathrm{X}=\mathrm{Cl}$

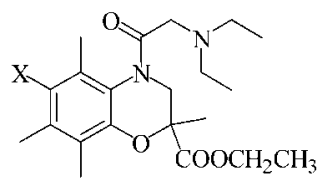

62: $X=H$

${ }^{a}$ Reagents and conditions: (a) $\mathrm{CH}_{3} \mathrm{C}(\mathrm{Br})\left(\mathrm{COOCH}_{2} \mathrm{CH}_{3}\right){ }_{2}, \mathrm{Cs}_{2} \mathrm{CO}_{3}$, TBAI, DMF, $40{ }^{\circ} \mathrm{C}$; (b) $\mathrm{H}_{2}, \mathrm{Pd} / \mathrm{C}$, EtOH, $50{ }^{\circ} \mathrm{C}$; (c) $\mathrm{AcOH}-\mathrm{H}_{2} \mathrm{O}_{2}-\mathrm{HCl}$, $\mathrm{PE}$, reflux; (d) Lawesson reagent, toluene $110{ }^{\circ} \mathrm{C}$; (e) Raney/nickel, EtOH- $\mathrm{H}_{2} \mathrm{O}$; (f) $\mathrm{BrCH}_{2} \mathrm{COBr}, \mathrm{Et}_{3} \mathrm{~N}, \mathrm{CH}_{2} \mathrm{Cl}_{2}$; (g) $\mathrm{Et}_{2} \mathrm{NH}$, toluene, $40{ }^{\circ} \mathrm{C}$.

Table 1. Antiarrhythmic and Antioxidant Activity of the New Analogues ${ }^{a}$

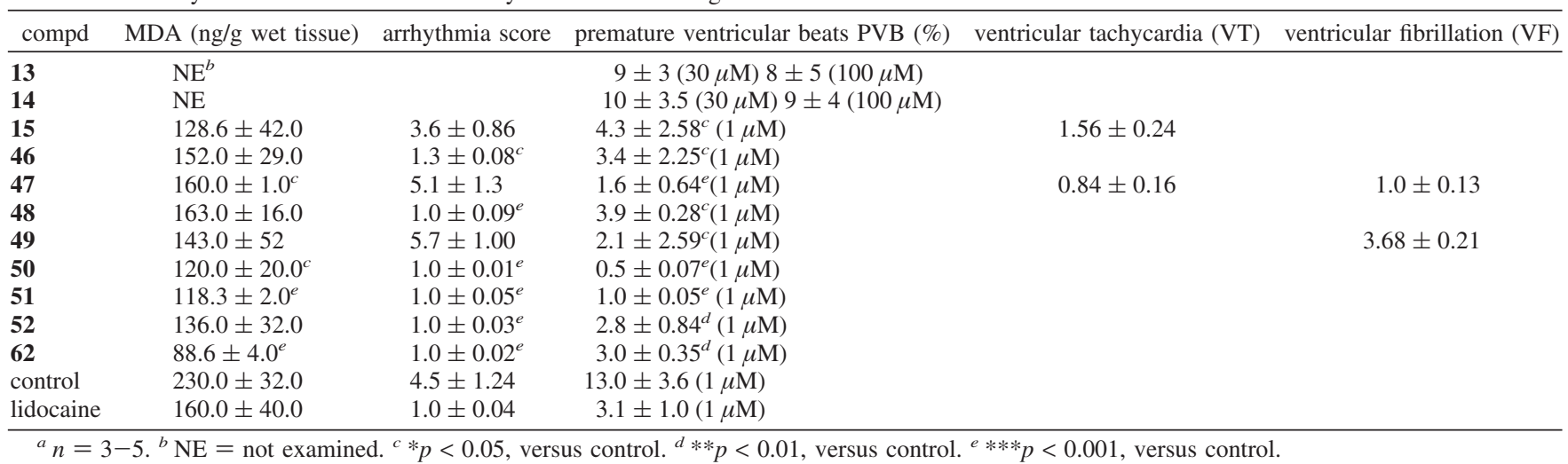

reperfusion. Arrhythmia scores were calculated for the first 10 min of reperfusion and were quantified according to the Lambeth Convention guidelines ${ }^{41}$ by the following scoring system: hearts with premature ventricular beats $\left(\mathrm{PVB}^{a}\right)$ less than $5 \%$ were given a score of 1, with PVB more than $5 \%$ or bigeminy/salvos a score of 2, ventricular tachycardia (VT) a score of 3, transient ventricular fibrillation (VF) a score of 4 , and sustained VF a score of 5. Ventricular fibrillations lasting more than $1 \mathrm{~min}$ were considered as sustained. The arrhythmia score in the absence of compound was $4.5 \pm 1.24$ and was mainly due to premature

${ }^{a}$ Abbreviations: APA, action potential amplitude, $\mathrm{APD}_{50}$, action potential duration measured at $50 \%$ repolarization; $\mathrm{APD}_{90}$, action potential duration measured at $90 \%$ repolarization; MDA, malondialdehyde; PVB, premature ventricular beats; RMP, resting membrane potential, $V_{\max }$, maximal rate of depolarization; VF, ventricular fibrillation, VT, ventricular tachycardia. beats $(13.0 \pm 3.6)$. Lidocaine had an arrhythmia score of $1.0 \pm$ 0.04 and was also due to premature beats $(3.1 \pm 1.0)$.

Peroxidation of membrane phospholipid polyunsaturated fatty acids is considered a major mechanism of the damage occurring on reperfusion of the myocardium after a prolonged period of ischemia. Lipid peroxides are unstable and decompose to form a series of compounds including reactive carbonyl compounds. Malondialdehyde (MDA) is the final product of lipid peroxidation, and it has been found in the blood of patients after reperfusion of the myocardium. ${ }^{42}$ Thus, malondialdehyde quantitation by the thiobarbituric acid test (TBA test) has been used as indicator of lipid peroxidation. ${ }^{43}$ Malondialdehyde (MDA) levels were measured at the end of reperfusion ( $\mathrm{ng} / \mathrm{g}$ wet tissue) (Tables 1,2), and the reduction of MDA levels was an indication of the antioxidant activity of the compounds under study. 
Table 2. Antiarrhythmic and Antioxidant Activity of the Racemic Mixture of Compound $\mathbf{5 1}$ and Its Enantiomers, 51a and 51b, Tested at $1 \mu \mathrm{M}$ Concentration $^{a}$

\begin{tabular}{|c|c|c|c|c|c|}
\hline compd & MDA (ng/g wet tissue) & arrhythmia score & premature ventricular beats PVB $(\%)$ & ventricular tachycardia (VT) & ventricular fibrillation (VF) \\
\hline 51 & $118.3 \pm 2.0^{b}$ & $1.0 \pm 0.05^{b}$ & $1.0 \pm 0.05^{b}$ & & \\
\hline 51a & $106.0 \pm 6.0^{b}$ & $4.3 \pm 1.34$ & $1.5 \pm 1.32^{c}$ & $2.64 \pm 0.32$ & $0.3 \pm 0.08$ \\
\hline $51 b$ & $153.0 \pm 34.0$ & $1.0 \pm 0.14^{b}$ & $0.80 \pm 0.07^{b}$ & & \\
\hline lidocaine & $160.0 \pm 40.0$ & $1.0 \pm 0.04$ & $3.1 \pm 1.0$ & & \\
\hline
\end{tabular}

${ }^{a} n=3-5 .^{b * * *} p<0.001$, versus control. ${ }^{c} * * p<0.01$, versus control.

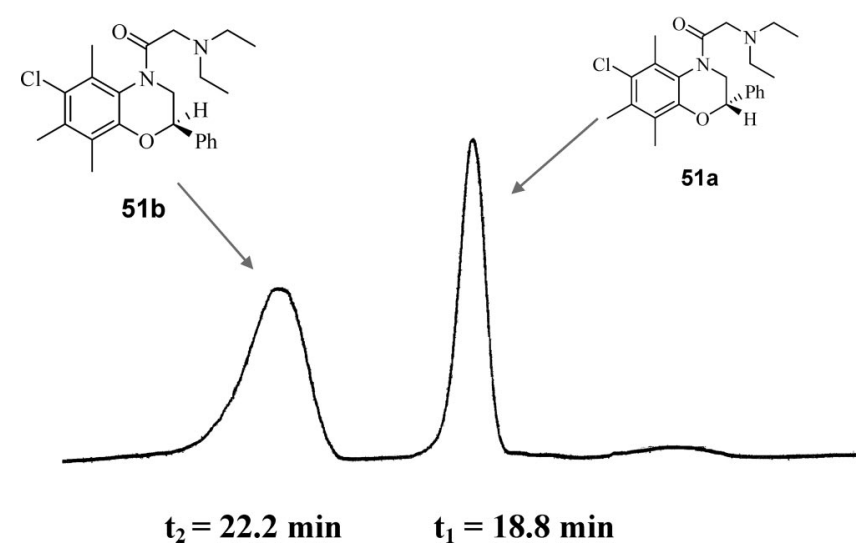

Figure 2. Chiral HPLC separation of racemic $\mathbf{5 1 .}$

The activity of compounds $\mathbf{1 3 - 1 5}, \mathbf{4 6}-\mathbf{5 2}$, and 62 against reperfusion arrhythmias and lipid peroxidation is presented in Table 1. Six out of the 11 new compounds induced only premature beats and therefore were given the arrhythmia score 1. When compared to the control value $(13.0 \pm 3.6)$, these compounds reduced significantly the occurrence of PVBs, although to a different extent.

In more detail, within the first group, the 6-hydroxy-5,7,8trimethyl-benzopyran-4-aminoamide compounds $\mathbf{1 3}$ and $\mathbf{1 4}$ were evaluated at 30 and $100 \mu \mathrm{M}$ and were found to possess low activity slightly suppressing premature beats. The levels of MDA were not measured because the compounds were not very potent. Conversely, introduction of a phenyl group at $\mathrm{C} 2$ resulted in increased activity and compound $\mathbf{1 5}$ at concentration of $2 \mu \mathrm{M}$ was found to reduce premature beats to $4.3 \pm 2.6$ with respect to the control $(13.0 \pm 3.6)$ and MDA levels by $45 \%$. However, tachycardia was observed as a side effect. (Table 1). On the contrary, the 5,7,8-trimethyl-1,4-benzoxazine derivatives 46-52, tested at $2 \mu \mathrm{M}$ (Table 1), were found to possess significant antioxidant and antiarrhythmic activity. The C2 and C6 unsubstituted derivative 46 reduced premature beats to $3.4 \pm 2.25$ with an arrhythmia score of $1.3 \pm 0.1$ versus the control (4.5 $\pm 1.24)$ and MDA levels by $34 \%$. Introduction of chlorine at C6, compound 48, reduced MDA levels by $29 \%$ and premature beats to $3.9 \pm 0.28$ with an arrhythmia score of $1.0 \pm 0.09$.

The 2,2-dimethyl derivative 47 significantly suppressed premature beats $(1.6 \pm 0.64)$ but caused tachycardia and ventricular fibrillation, resulting in an arrhythmia score of 5.1 \pm 1.3 . The presence of a chlorine atom at C6 in 47 (compound 49) caused also reduction of PVBs $(2.1 \pm 2.59)$ and suppressed tachycardia but increased fibrillation (arrhythmia score $5.7 \pm$ 1.00). The antioxidant capacity of $\mathbf{4 7}$ and $\mathbf{4 9}$ was similar.

The 2-phenyl substituted analogues 50-52 exhibited the highest antioxidant and antiarrhythmic activity of all the compounds of the present study. Thus, derivative $\mathbf{5 0}$ decreased MDA levels by approximately $48 \%$ and PVBs to $0.5 \pm 0.07$ (control PVB $(\%)=13 \pm 3.6$ and lidocaine PVB $(\%)=3.1 \pm$ 1.0).
The C6 chloro-substituted analogue of $\mathbf{5 0}$ (compound 51) reduced PVBs to a lesser extent than $\mathbf{5 0}(\mathrm{PVB}=1.0 \pm 0.05)$ but possessed slightly higher antioxidant activity $(118.3 \pm 2.0$ $\mathrm{ng} / \mathrm{g}$ wet tissue). In addition, both compounds resulted in very good recovery of the heart. Analogue $\mathbf{5 2}$ is substituted by a methoxy group at C6 and caused a substantial decrease of PVBs and MDA in comparison to both the control and lidocaine (PVB $=2.8 \pm 0.84$ and MDA $=136 \pm 32.0 \mathrm{ng} / \mathrm{g}$ wet tissue). However, when compared to $\mathbf{5 0}$ and $\mathbf{5 1}$, the presence of the methoxy group was less advantageous than chlorine or hydrogen.

Because compound $\mathbf{5 1}$ was not only very potent in suppressing reperfusion arrhythmias but also was the most potent antioxidant (MDA $118.3 \pm 2.0 \mathrm{ng} / \mathrm{g}$ wet tissue), it was of interest to investigate whether the two enantiomers of $\mathbf{5 1}$ possessed different activity than the racemate. Thus we employed chiral HPLC (DAICEL-CHIRACEL OD, mobile phase hexane/2-propanol 90/10, flow rate $2.4 \mathrm{~mL} / \mathrm{min}$ ) for the separation of the racemic mixture (Figure 2). The first eluting enantiomer $\left(t_{1}=18.8 \mathrm{~min}\right) \mathbf{5 1 a}\left([\alpha]_{D}^{20}=+41.3^{\circ}\right)$ reduced the MDA levels more than $50 \%(106.0 \pm 6.0)$ and the PVBs to 1.5 \pm 1.32 but it caused tachycardia and fibrillation (Table 2$)$. The second eluting enantiomer $\left(t_{2}=22.2 \mathrm{~min}\right) \mathbf{5 1 b}\left([\alpha]_{D}^{20}=-42.8^{\circ}\right)$ almost totally suppressed reperfusion arrhythmias PVB $(\%)=$ $0.80 \pm 0.07$, reduced MDA (153.0 \pm 34.0$)$, not as efficiently as 51a, and resulted in very good recovery of the heart. To determine the absolute stereochemistry of the active enantiomer 51b, we performed chiral synthesis, as depicted in Scheme 6, and it was found that compound $\mathbf{5 1 b}$ was the $R$-enantiomer. It must be noted that even though the two enantiomers differed in activity, the racemic mixture was equally active as $\mathbf{5 1 b}$. This has been previously reported for the racemate of the $\beta$-adrenergic blocker and class III antiarrhythmic, sotalol and its dextrorotatory isomer (D-sotalol), which were both equally effective in increasing cardiac action potential durations. ${ }^{44}$

The antiarrhythmic and the antioxidant capacity of the trolox resembling derivative $\mathbf{6 2}$ were also measured using the same conditions (Table 1). This compound was found to possess the highest antioxidant capacity as reduced the level of MDA to approximately $40 \%$ of the control $(p<0.001)$, while its antiarrhythmic activity was similar to that of compounds $\mathbf{5 0 - 5 2}$.

To get an insight on the mechanism of action of the potent 5,7,8-trimethyl-1,4-benzoxazine derivatives, we employed the conventional microelectrode technique to study their effects on the action potential parameters. More specifically, we selected the nonsubstituted at $\mathrm{C} 2$ and C6 compounds 46 and 47, which bear two methyl groups at $\mathrm{C} 2, \mathbf{4 9}$, which is the 6-chloro derivative of $\mathbf{4 7}, \mathbf{5 0}$, which has a phenyl substituent at $\mathrm{C} 2$, and the two trolox-resembling derivatives 62 and $\mathbf{6 3}$.

The cellular electrophysiological effects of analogues 46, 47, 49, 50, 62, and 63 were investigated using rabbit right ventricular papillary muscle at $5 \mu \mathrm{M}$. As control, we employed the class I/B drug mexiletine, which is an orally active lidocaine analogue, and the class III antiarrhythmic sotalol, at $20 \mu \mathrm{M}$ concentration (Figure 3). The relation of the in vitro cellular action potential and in vivo ECG measurements is illustrated in Figure 4. The 


\section{Scheme $6^{a}$}

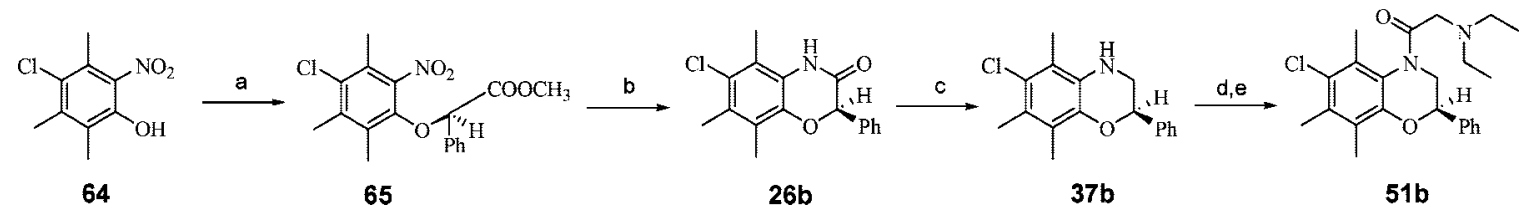

${ }^{a}$ Reagents and conditions: (a) (S)-(+)- $\alpha$-Hydroxy-phenyl-acetic acid methyl ester, $\mathrm{Ph}_{3} \mathrm{P}, \mathrm{DEAD}$, THF, ultrasound; $(\mathrm{b}) \mathrm{Fe}, \mathrm{NH} \mathrm{H}_{4} \mathrm{Cl}, \mathrm{EtOH} / \mathrm{H}_{2} \mathrm{O}, 85^{\circ} \mathrm{C}$; (c) $\mathrm{BH}_{3} \cdot \mathrm{SMe}_{2}$, THF; (d) $\mathrm{BrCH}_{2} \mathrm{COBr}, \mathrm{Et}_{3} \mathrm{~N}, \mathrm{CH}_{2} \mathrm{Cl}_{2}$; (e) $\mathrm{Et}_{2} \mathrm{NH}$, toluene, $40{ }^{\circ} \mathrm{C}$.

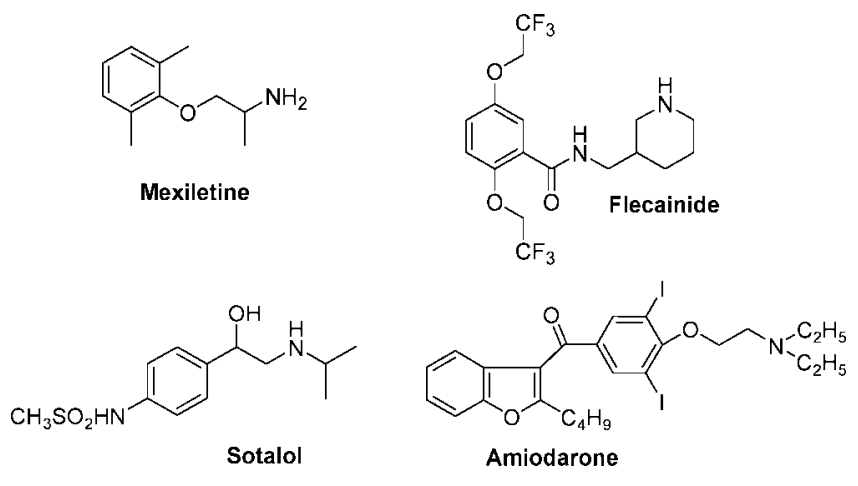

Figure 3. Structures of known antiarrhythmic drugs.

cellular electrophysiological results are illustrated and summarized in Table 3 and Figures 5 and 6. The compounds can be divided in three groups according to their effects. Thus, compounds 47 and 63 did not or only slightly changed the repolarization measured as $\mathrm{APD}_{50}$ or $\mathrm{APD}_{90}$ but exerted marked and use-dependent depression of the maximal rate of depolarization $\left(V_{\max }\right)$ and increase of impulse conduction time (CT), particularly at fast stimulation frequencies. In this respect, it has to be noted that $\mathbf{4 7}$ decreased $V_{\max }$ only at stimulation cycle lengths shorter than 1500-2000 ms, while, $\mathbf{6 3}$ decreased $V_{\max }$ at all stimulation cycle lengths studied. These effects resemble those of mexiletine (Figure 6$)^{45}$ and flecainide, ${ }^{46}$ are consistent with class I/B and class I/C properties ${ }^{47}$ and strongly suggest considerable fast sodium channel inhibition. Compounds $\mathbf{4 6}$ and 49 induced a marked reverse rate dependent prolongation of repolarization measured as $\mathrm{APD}_{90}$ without or only slightly changing $V_{\max }$ or CT. This effect by $\mathbf{4 6}$ is similar to the class III reference compound sotalol (Figure 6) and is consistent with class III antiarrhythmic properties, ${ }^{48}$ suggesting inhibition of one of the repolarizing cardiac potassium channels most likely the rapid delayed rectifier outward potassium current $\left(I_{\mathrm{Kr}}\right)$ flowing through the HERG channels. Compounds $\mathbf{5 0}$ and $\mathbf{6 2}$ showed considerable effect both on repolarization $\left(\mathrm{APD}_{90}\right)$ and depolarization/impulse conduction in a frequency dependent manner. Both analogues decreased $V_{\max }$ and increased CT more at fast stimulation frequencies corresponding to cycle lengths of less than $2000 \mathrm{~ms}$ than at normal or slow ones, but they delayed repolarization reflected as increase of $\mathrm{APD}_{90}$ somewhat more at slow than at fast stimulation frequencies. This combination of class IB and class III antiarrhythmic properties resembles to that of amiodarone ${ }^{49}$ and suggests combined or multichannel drug action.

The 2,2-dialkyl-substituted-4-aminobenzopyrane derivatives 13 and 14 possessed similar antiarrhythmic activity as their 5 -aminobenzopyrane congeners, previously reported by our group. ${ }^{28}$ This suggests that the position of the aminoamide functionality in the 2,2-dialkyl-chroman derivatives is not very critical for activity against reperfusion arrhythmias. The presence of alkyl substituents at $\mathrm{C} 2$ resulted either in moderately active compounds, in the case of the 4-amino-benzopyran derivatives
13 and 14, or in analogues that caused ventricular tachycardia and/or ventricular fibrillation, 47 and $\mathbf{4 9}$, respectively. Conversely, the presence of a phenyl group at $\mathrm{C} 2$ resulted in potent compounds in both the 5,7,8-trimethyl-1,4-benzoxazine and the 5,7,8-trimethyl-benzopyran series. This effect was more pronounced within the 1,4-benzoxazine analogues because all 2-phenyl substituted derivatives 50-53 resulted in very good recovery of the heart after ischemia-reperfusion. The troloxinspired-1,4-benzoxazinic derivative $\mathbf{6 2}$, reduced reperfusion arrhythmias, and resulted in an extremely low MDA level, even lower than the nonperfused heart. We cannot give a reasonable explanation for this result based on the biological experiments performed so far.

The presence of a C6-chloro-substituent in 5,7,8-trimethyl1,4-benzoxazines did not affect the antioxidant capacity and the arrhythmia score with respect to the nonchlorinated congeners, but it resulted in differences on the action potential parameters. A possible explanation could be differences in membrane binding and permeation due to halogenation, as previously reported. ${ }^{50}$

As a general observation, the 5,7,8-trimethyl-1,4-benzoxazine scaffold resulted in more potent antiarrhythmic compounds when compared to the 5,7,8-trimethyl-benzopyransubstituted derivatives. This is not unexpected because the $2 H$-1,4-benzoxazine-3-(4H)-one and 3,4-dihydro- $2 \mathrm{H}$-1,4-benzoxazine systems have been studied extensively for building natural and designed biologically active compounds, which span from herbicides, fungicides, cardiovascular agents, $\mathrm{K}_{\text {ATP }}$ channel openers, compounds against diabetes, neuroprotectants, and agents against anxiety and depression. ${ }^{51-53}$ Thus, the above-mentioned heterocycles can be considered as privileged scaffolds for the development of potential new drugs. To the best of our knowledge, the 5,7,8-trimethyl1,4-benzoxazine moiety has not been utilized yet as a template for the design of new antiarrhythmics. The presence of the three methyl substituents renders the system so electron rich that the corresponding 6-hydroxy-2-alkyl- or 6-hydroxy2-aryl-5,7,8-trimethyl-1,4-benzoxazines were not stable ${ }^{54}$ in contrast to the 6-methoxy-derivative $\mathbf{5 2}$.

Concerning the effect of the new analogues on action potential parameters, we cannot draw specific structure-activity relationships, however it is evident that the compounds that suppressed reperfusion arrhythmias and did not induce ventricular tachycardia and/or ventricular fibrillation possess a multichannel profile. In addition, we cannot deduce any clear trend between MDA reduction and suppression of reperfusion arrhythmias for the compounds tested. It is possible that our compounds affect pathways of ischemiareperfusion injury, which are not reflected on the MDA produced. However, the analogues that effectively suppressed reperfusion arrhythmias reduced MDA levels with respect to the control.

In conclusion, we have synthesized 5,7,8-trimethylbenzopyran and 5,7,8-trimethyl-1,4-benzoxazine derivatives encompassing the pharmacophore aminoamide functionality of lidocaine. On 


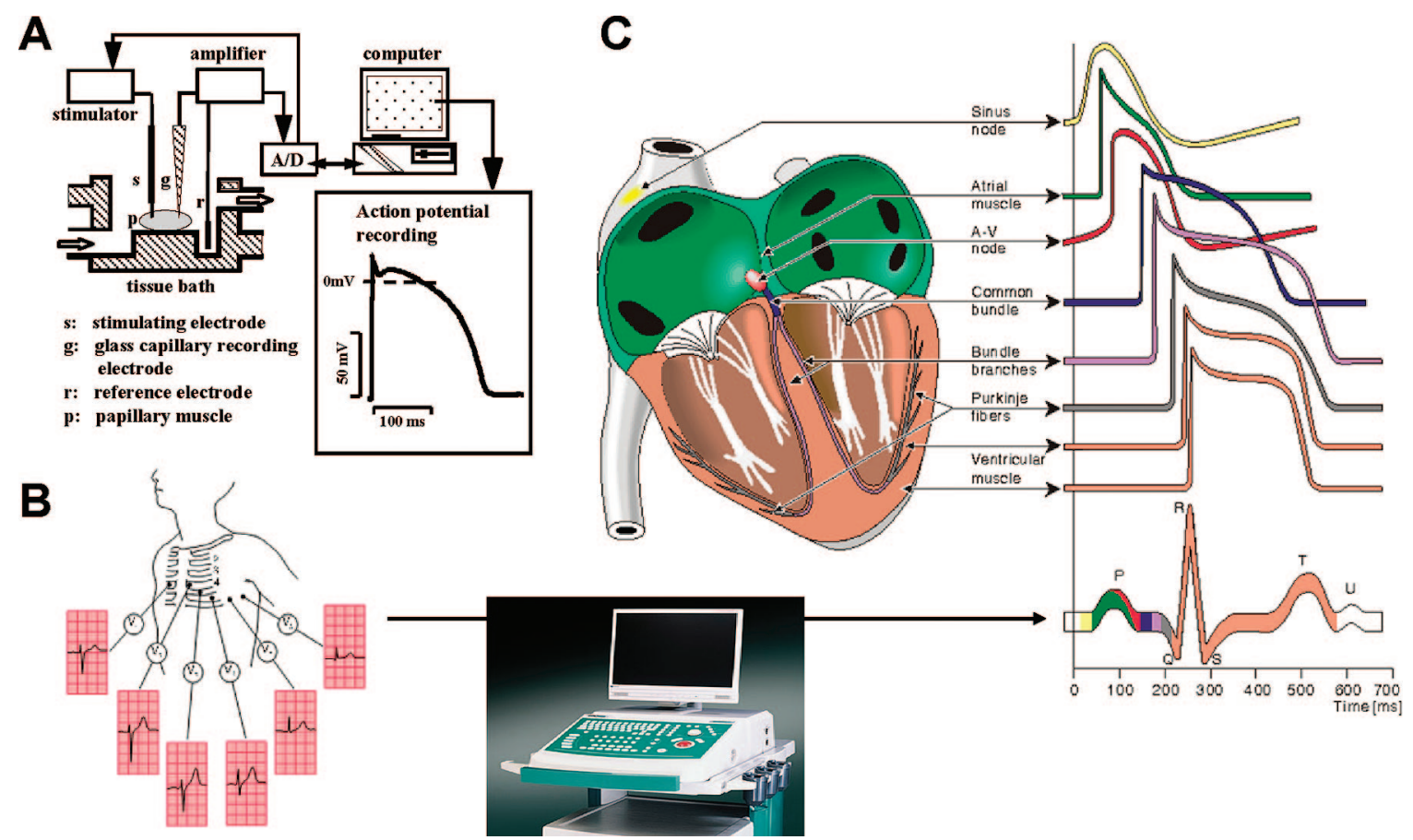

Figure 4. (A) Arrangement of the intracellular action potential measurement. A fine glass sharp tip microelectrode was inserted into the intracellular space and the other (reference) electrode was placed at the extracellular environment. The potential difference between the two electrodes was measured through an amplifier and represents the electrical activity of the ventricular papillary muscle cells. (B) Body surface electrocardiogram (ECG), which represents the electrical activity of the whole heart and commonly used in the clinical practice. (C) Illustration of the relation between the intracellular action potential and the ECG recordings. The ECG signal represents the average of the large number of action potentials produced by the individual myocardial cells measured at the body surface. The $\mathrm{P}$ wave corresponds to the activity of the atrial cells, the QRS and T waves the depolarization and the repolarization of the ventricular myocytes, respectively. Therefore, as the figure shows changes of the maximal rate of depolarization $\left(V_{\max }\right)$ would result changes in the QRS waves and changes in the ventricular action potential duration would result changes in the QT interval.

Table 3. Effect of Compounds 46, 47, 49, 50, 62, and 63 and Reference Drugs Sotalol and Mexiletine on the Action Potential Parameters in Rabbit Right Ventricular Papillary Muscle at $1 \mathrm{~Hz}$ Stimulation Frequency

\begin{tabular}{|c|c|c|c|c|c|}
\hline $\operatorname{compd}^{a}$ & $\mathrm{RMP},{ }^{e} \mathrm{mV}$ & $\mathrm{APA},{ }^{f} \mathrm{mV}$ & $\mathrm{APD}_{50},{ }^{g} \mathrm{~ms}$ & $\mathrm{APD}_{90},{ }^{g} \mathrm{~ms}$ & $V_{\max },{ }^{h} \mathrm{~V} / \mathrm{s}$ \\
\hline $46^{b}$ & $-85.8 \pm 0.3$ & $111.9 \pm 1.9$ & $192.3 \pm 7.5$ & $236.8 \pm 6.5$ & $200.2 \pm 18.2$ \\
\hline control $^{b}$ & $-86.5 \pm 0.9$ & $111.6 \pm 1.7$ & $160.7 \pm 10.7$ & $205.3 \pm 9.1$ & $220.2 \pm 15.2$ \\
\hline 47 & $-85.9 \pm 1.0$ & $108.4 \pm 2.8$ & $147.1 \pm 11.7$ & $179.5 \pm 10.1$ & $175.4 \pm 25.8$ \\
\hline 49 & $-85.3 \pm 2.0$ & $116.2 \pm 1.7$ & $171.6 \pm 3.5$ & $214.4 \pm 3.5$ & $188.4 \pm 14.5$ \\
\hline control & $-84.0 \pm 2.5$ & $115.4 \pm 2.1$ & $155.8 \pm 7.7$ & $195.4 \pm 7.6$ & $197.0 \pm 9.3$ \\
\hline 50 & $-82.7 \pm 3.4$ & $115.1 \pm 3.1$ & $175.6 \pm 12.9$ & $210.9 \pm 12.4$ & $174.5 \pm 15.4$ \\
\hline control & $-84.4 \pm 2.3$ & $114.4 \pm 2.6$ & $149.8 \pm 7.0$ & $185.9 \pm 5.2$ & $203.3 \pm 15.2$ \\
\hline 63 & $-81.5 \pm 3.4$ & $105.1 \pm 4.2$ & $107.7 \pm 11.8$ & $159.5 \pm 5.0$ & $184.7 \pm 8.7$ \\
\hline control & $-83.7 \pm 2.1$ & $109.8 \pm 0.9$ & $110.0 \pm 11.7$ & $161.7 \pm 5.3$ & $251.7 \pm 25.9$ \\
\hline sotalol $^{c}$ & $-85.9 \pm 1.8$ & $109.5 \pm 2.1$ & $219.9 \pm 23.3$ & $275.0 \pm 24.8$ & $202.4 \pm 18.6$ \\
\hline control & $-87.9 \pm 1.7$ & $109.8 \pm 1.7$ & $153.8 \pm 11.1$ & $198.6 \pm 10.7$ & $220.2 \pm 21.9$ \\
\hline mexiletine $^{d}$ & $-85.7 \pm 2.0$ & $105.9 \pm 2.9$ & $141.0 \pm 10.6$ & $180.9 \pm 10.6$ & $190.3 \pm 19.7$ \\
\hline control & $-83.6 \pm 0.9$ & $106.2 \pm 1.3$ & $139.7 \pm 8.5$ & $179.6 \pm 8.7$ & $200.7 \pm 9.5$ \\
\hline
\end{tabular}

${ }^{a} n=3 .{ }^{b} n=4 .{ }^{c} n=7$ (reference compound). ${ }^{d} n=10$ (reference compound). ${ }^{e} \mathrm{RMP}=$ resting membrane potential. ${ }^{f}$ APA $=$ action potential amplitude. ${ }^{g} \mathrm{APD}_{50}, \mathrm{APD}_{90}=$ action potential duration measured at $50 \%$ and $90 \%$ repolarization, respectively. ${ }^{h} V_{\max }=$ maximal rate of depolarization.

the basis of the evaluation of the antiarrhythmic and antioxidant properties as well as the cellular cardiac electrophysiological properties of the studied analogues $\mathbf{5 0}$ and $\mathbf{6 2}$ are promising compounds for further studies because of their multichannel "amiodarone like" effect, less proarrhythmic complications can be expected than with $\mathbf{4 7}, \mathbf{6 3}, \mathbf{4 6}$, and 49 , which seem to have either class I or class III actions, which were responsible to the increased mortality in the CAST ${ }^{2}$ and SWORD ${ }^{55}$ multicenter clinical trials. However, it has to be emphasized that further studies are needed to establish the exact mode of action of the studied compounds because several possible potential antiarrhythmic mechanisms like calcium, ATP, acetylcholine ultra rapid delayed rectifier ( $I_{\text {Kur }} \mathrm{kV} 1.5$ ) channel, or $\beta$ receptor block can not be ruled out.

\section{Experimental Section}

NMR spectra were recorded on a Bruker AC 300 spectrometer operating at $300 \mathrm{MHz}$ for ${ }^{1} \mathrm{H}$ and $75.43 \mathrm{MHz}$ for ${ }^{13} \mathrm{C}$. ${ }^{1} \mathrm{H} \mathrm{NMR}$ spectra are reported in units of $\delta$ relative to the internal standard of signals of the remaining protons of deuterated chloroform, at $7.24 \mathrm{ppm} .{ }^{13} \mathrm{C}$ NMR shifts are expressed in units of $\delta$ relative to $\mathrm{CDCl}_{3}$ at $77.0 \mathrm{ppm} .{ }^{13} \mathrm{C}$ NMR spectra were proton noise decoupled. All NMR spectra were recorded in $\mathrm{CDCl}_{3}$. Silica gel plates Macherey-Nagel Sil G-25 $\mathrm{UV}_{254}$ were used for thin layer chromatography. Chromatographic purification was performed with silica 

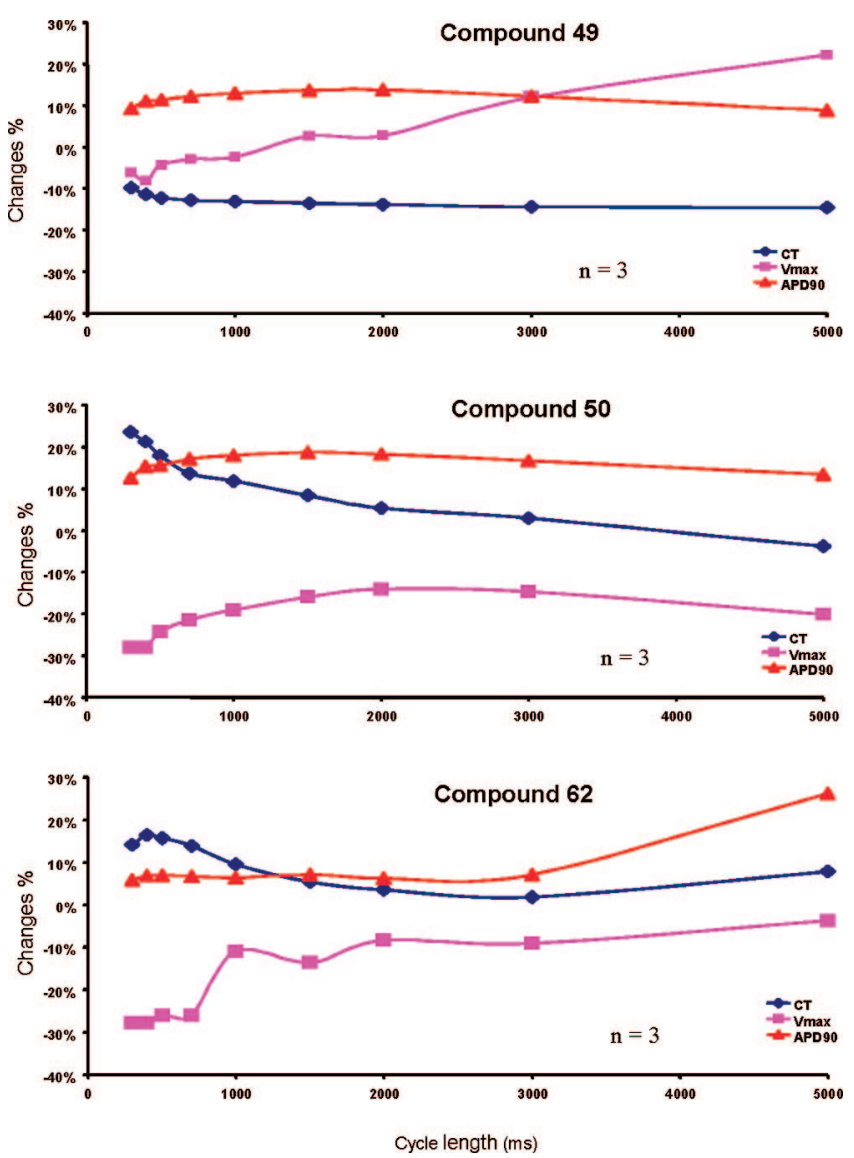

Figure 5. Frequency dependent effect of compounds 49, 50, and 62 on the conduction time $(\mathrm{CT})$, maximal rate of depolarization $\left(V_{\max }\right)$, and action potential duration (APD90) on rabbit ventricular papillary muscles.

gel (200-400 mesh). Elemental analyses were carried out on a Perkin-Elmer series II CHNS/O 2400 analyzer. Mass spectra were recorded on a Varian Saturn 2000 GC-MS instrument in the EI mode.

2,3-Dihydro-2-phenyl-6-hydroxy-2,5,7,8-tetramethyl-4H-1benzopyran-4-one (3). 2,4,5-Trimethyl-3,6-dihydroxyacetophenone $(1.94 \mathrm{~g}, 10 \mathrm{mmol})$ and benzaldehyde $(1.04 \mathrm{~mL}, 10 \mathrm{mmol})$ were added to a mixture of $\mathrm{H}_{3} \mathrm{BO}_{3}(0.927 \mathrm{~g}, 15 \mathrm{mmol})$, piperidine $(0.25$ $\mathrm{mL}, 2.5 \mathrm{mmol})$, and $\mathrm{SiO}_{2}(2.5 \mathrm{~g})$ in DMF $(20 \mathrm{~mL})$. The mixture was stirred at $120{ }^{\circ} \mathrm{C}$ overnight, and then it was cooled to room temperature and was diluted with acetone and filtered. The filtrate was evaporated in vacuo to afford benzopyranone $\mathbf{3}$ as viscous oil $(0.9 \mathrm{~g}, 34 \%)$, which was used without further purification in the next step. ${ }^{1} \mathrm{H}$ NMR $(\delta) 7.5-7.34(\mathrm{~m}, 5 \mathrm{H}), 5.41(\mathrm{~d}, J=12.8 \mathrm{~Hz}$, 1H), 3.05-2.84 (m, 2H), 2.47 (s, 3H), 2.21 (s, 3H), 2.13 (s, 3H). ${ }^{13} \mathrm{C}$ NMR $(\delta) 193.5,158.3,142.5,139.3,137.2,129.7,128.7,128.4$, $125.8,124.4,117.6,78.5,20.4,14.1,14.0,12.2$.

2,3-Dihydro-2-phenyl-6-hydroxy-5,7,8-trimethyl-4H-1-benzopyran-4-one-oxime (6). Oxime 6 was prepared according to the procedure described for oxime $\mathbf{4}$ using benzopyranone $\mathbf{3}$, dry pyridine $(5 \mathrm{~mL})$, and hydroxylamine hydrochloride $(0.963 \mathrm{~g}, 13.9$ mmol) $0.21 \mathrm{~g}, 92 \%$ yield. ${ }^{1} \mathrm{H}$ NMR $(\delta) 7.52-7.32(\mathrm{~m}, 5 \mathrm{H}), 4.95$ $(\mathrm{dd}, J=12.8 \mathrm{~Hz}, J=3.7 \mathrm{~Hz}, 1 \mathrm{H}), 3.50(\mathrm{dd}, J=17.7 \mathrm{~Hz}, J=3.7$ $\mathrm{Hz}, 1 \mathrm{H}), 2.90(\mathrm{dd}, J=17.7 \mathrm{~Hz}, J=12.2 \mathrm{~Hz}, 1 \mathrm{H}), 2.50(\mathrm{~s}, 3 \mathrm{H})$, $2.22(\mathrm{~s}, 3 \mathrm{H}), 2.19(\mathrm{~s}, 3 \mathrm{H}) .{ }^{13} \mathrm{C}$ NMR $(\delta) 153.6,150.2,146.8,140.6$, $128.5,127.9,125.9,125.8,123.7,118.5,115.9,77.2,32.9,14.7$, 12.7, 12.1 .

4-Amino-3,4-dihydro-2-phenyl-5,7,8-trimethyl-2H-1-benzopyran-6-ol (9). To a solution of $\mathrm{TiCl}_{4}(0.17 \mathrm{~mL}, 1.53 \mathrm{mmol})$ in dimethoxyethane $(2 \mathrm{~mL})$ at $0{ }^{\circ} \mathrm{C}$ was added $\mathrm{NaBH}_{4}(116 \mathrm{mg}, 3.06$ $\mathrm{mmol})$. The mixture was stirred at $0{ }^{\circ} \mathrm{C}$ for $10 \mathrm{~min}$, and subsequently a solution of oxime $6(0.15 \mathrm{~g}, 0.51 \mathrm{mmol})$ in $2 \mathrm{~mL}$
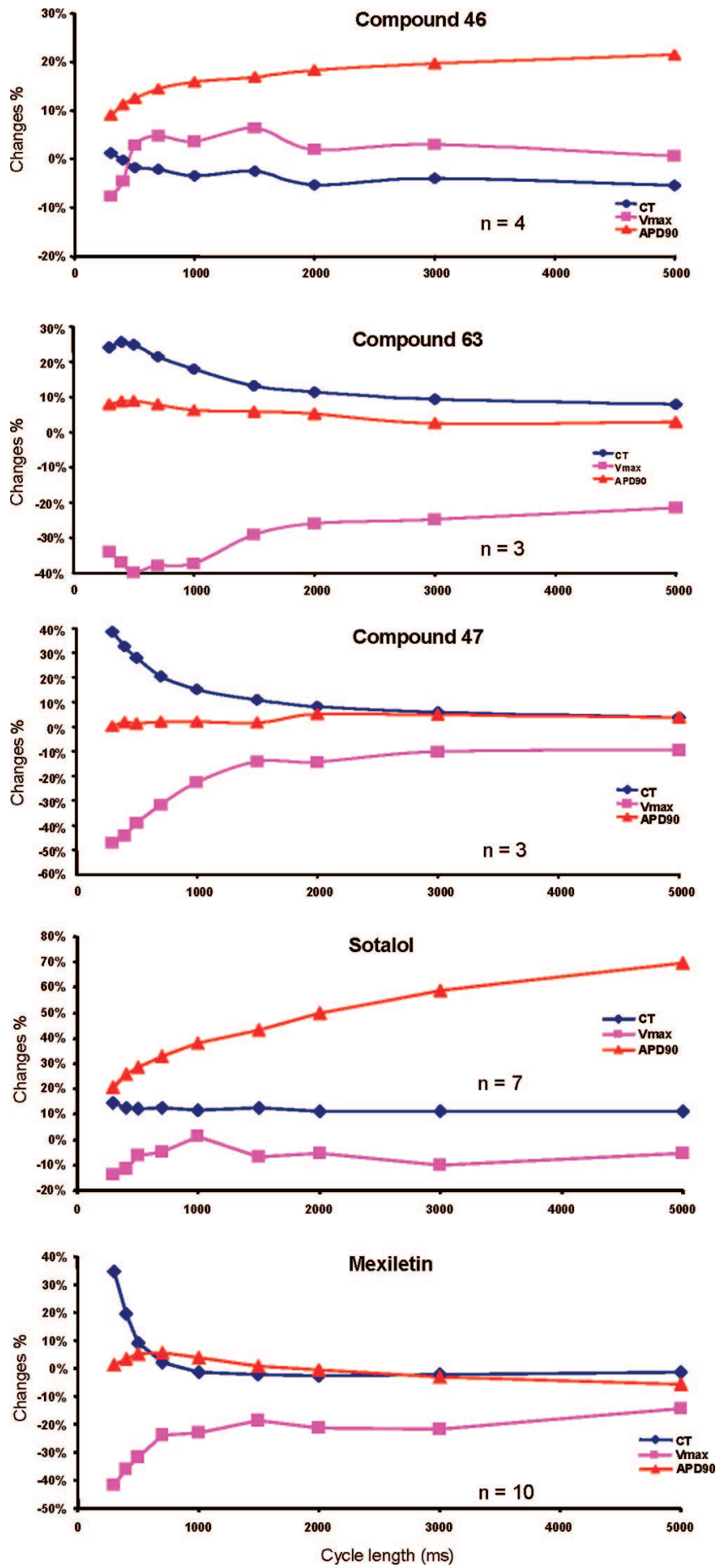

Figure 6. Frequency dependent effect of compounds 46, 47, and 63 and reference drugs sotalol and mexiletine on the conduction time (CT), maximal rate of depolarization $\left(V_{\max }\right)$, and action potential duration (APD90) on rabbit ventricular papillary muscles.

dimethoxyethane was added dropwise. The mixture was stirred at room temperature overnight. The reaction mixture was cooled to 0 ${ }^{\circ} \mathrm{C}$ and water was added. The mixture was made basic with the addition of $28 \%$ aqueous ammonia and was extracted with dichloromethane. The organic layer was extracted with brine, was dried $\left(\mathrm{Na}_{2} \mathrm{SO}_{4}\right)$, and the solvent was evaporated in vacuo to afford 9, which was used without further purification. Viscous oil, 0.121 g, yield: $84 \% .{ }^{1} \mathrm{H}$ NMR $(\delta)$ 7.46-7.29 (m, 5H), 5.26-4.95 (m, $1 \mathrm{H}), 4.07-4.16(\mathrm{~m}, 1 \mathrm{H}), 2.24-2.12(\mathrm{~m}, 11 \mathrm{H})$.

$N$-(3,4-Dihydro-2-phenyl-6-hydroxy-5,7,8-trimethyl-2H-1benzopyran-4-yl)-bromoacetamide (12). To a solution of 4-amino3,4-dihydro-2-phenyl-5,7,8-trimethyl-2H-1-benzopyran-6-ol (9) (85 
$\mathrm{mg}, 0.30 \mathrm{mmol}$ ) in a mixture of $\mathrm{THF} / \mathrm{H}_{2} \mathrm{O} 3 / 2$ at $0{ }^{\circ} \mathrm{C}$ was added $\mathrm{NaHCO}_{3}$ followed by the dropwise addition of bromoacetylchloride $(0.60-1.2 \mathrm{mmol})$ until completion of the reaction by TLC. The reaction mixture was diluted with dichloromethane, and the organic layer was washed with saturated aqueous $\mathrm{NaHCO}_{3}$, brine, and was dried over $\mathrm{Na}_{2} \mathrm{SO}_{4}$. The solvent was evaporated in vacuo to afford the desired bromoacetamide 12, which was used without further purification. Viscous oil, $0.295 \mathrm{~g}, 73 \%$ yield. ${ }^{1} \mathrm{H}$ NMR $(\delta)$ 7.54-7.30 (m, 5H), 5.23-4.91 (m, 1H), 4.11-4.32 (m, $1 \mathrm{H})$, $3.92-3.49$ (m, 2H), 2.25-1.99 (m, 11H).

$\mathrm{N}$-(3,4-Dihydro-2-phenyl-6-hydroxy-5,7,8-trimethyl-2H-1benzopyran-4-yl)-(diethylamino)acetamide (15). To a solution of $\mathrm{N}$-(3,4-dihydro-2-phenyl-6-hydroxy-5,7,8-trimethyl-2H-1-benzopyran-4-yl)-bromoacetamide (12) (113 mg, $0.28 \mathrm{mmol})$ in $7 \mathrm{~mL}$ toluene at $0{ }^{\circ} \mathrm{C}$ was added diethylamine $(0.07 \mathrm{~mL}, 0.70 \mathrm{mmol})$. After stirring for 2 days at room temperature, the mixture was extracted with $2 \mathrm{~N} \mathrm{HCl}$. The aqueous layer was made basic with 2 $\mathrm{N} \mathrm{NaOH}$ and extracted with $\mathrm{CH}_{2} \mathrm{Cl}_{2}$. The organic layer was dried $\left(\mathrm{Na}_{2} \mathrm{SO}_{4}\right)$ and the solvent was evaporated in vacuo. Purification of the residue by flash column chromatography using dichloromethane/ methanol 98:2 as elution solvent, compound $\mathbf{1 5}$ was obtained as a gummy solid (0.086 g, 78\%). ${ }^{1} \mathrm{H}$ NMR $(\delta) 7.41-7.29(\mathrm{~m}, 5 \mathrm{H})$, $5.40-4.89(\mathrm{~m}, 1 \mathrm{H}), 4.32-4.11(\mathrm{~m}, 1 \mathrm{H}), 3.64-1.98(\mathrm{~m}, 17 \mathrm{H})$, $1.04-0.85(\mathrm{~m}, 6 \mathrm{H}) .{ }^{13} \mathrm{C}$ NMR $(\delta) 173.8,150.1,146.5,140.8,128.3$, $127.6,125.2$, 125.1, 123.9, 118.7, 115.6, 77.1, 59.9, 48.5, 41.1, 39.8, 14.5, 12.5, 12.2, 11.8. Anal. $\left(\mathrm{C}_{24} \mathrm{H}_{32} \mathrm{~N}_{2} \mathrm{O}_{3}\right) \mathrm{C}, \mathrm{H}, \mathrm{N}$.

2-Nitro-3,5,6-trimethylphenol (17). A solution containing 2,3,5trimethylphenol (16) $(6.0 \mathrm{~g}, 44 \mathrm{mmol})$ in diethyl ether $(100 \mathrm{~mL})$ was added dropwise to a solution of sodium nitrate $(3.71 \mathrm{~g}, 44$ $\mathrm{mmol})$ and $\mathrm{La}(\mathrm{NO})_{3} \cdot 6 \mathrm{H}_{2} \mathrm{O}(0.191 \mathrm{~g}, 0.44 \mathrm{mmol})$ in $6 \mathrm{~N} \mathrm{HCl}(72$ $\mathrm{mL}$ ) at $0{ }^{\circ} \mathrm{C}$. The reaction mixture was stirred at room temperature for $1 \mathrm{~h}$ and was then extracted with ethyl acetate. The organic layer was washed with brine, dried $\left(\mathrm{Na}_{2} \mathrm{SO}_{4}\right)$, and the solvent was evaporated in vacuo. The residue was purified by flash column chromatography (petroleum ether $40-60{ }^{\circ} \mathrm{C} /$ acetone 95:5) to afford 2-nitro-3,5,6-trimethylphenol as yellow solid (5.19 g, 65\% yield): mp 74-77 ${ }^{\circ} \mathrm{C} .{ }^{1} \mathrm{H}$ NMR $(\delta) 11.02(\mathrm{~s}, 1 \mathrm{H}), 6.62(\mathrm{~s}, 1 \mathrm{H}), 2.55(\mathrm{~s}$, $3 \mathrm{H}), 2.27(\mathrm{~s}, 3 \mathrm{H}), 2,18(\mathrm{~s}, 3 \mathrm{H}) .{ }^{13} \mathrm{C}$ NMR $(\delta) 153.8,145.4,133.2$, 132.9, 125.1, 124.4, 124.2, 22.5, 20.5, 11.6. MS (EI), m/z: 181 (100, $\left.\mathrm{M}^{+}\right)$. Anal. $\left(\mathrm{C}_{9} \mathrm{H}_{11} \mathrm{NO}_{3}\right) \mathrm{C}, \mathrm{H}, \mathrm{N}$.

2-Methyl-2-(2,3,5-trimethyl-6-nitrophenoxy)propanoic Acid Ethyl Ester (19). To a solution of 2-nitro-3,5,6-trimethylphenol (17) $(0.4 \mathrm{~g}, 2.21 \mathrm{mmol})$ in dry DMF $(7.35 \mathrm{~mL})$ was added cesium carbonate $(2.16 \mathrm{~g}, 6.62 \mathrm{mmol})$, TBAI (catalytic amount), and 2-bromo-2-methyl-propionic acid ethyl ester $(0.97 \mathrm{~mL}, 6.62 \mathrm{mmol})$ and the mixture was heated at $60{ }^{\circ} \mathrm{C}$ for three days. Subsequently, the reaction the mixture was diluted with water and extracted with ethyl acetate. The organic layer was washed with brine and dried $\left(\mathrm{Na}_{2} \mathrm{SO}_{4}\right)$. The solvent was evaporated in vacuo, and the crude product was purified by flash column chromatography (petroleum ether $40-60{ }^{\circ} \mathrm{C} /$ acetone (95:5)) to afford compound 19 as a viscous oil, $0.487 \mathrm{~g}, 83 \%$ yield. ${ }^{1} \mathrm{H}$ NMR $(\delta) 6.78(\mathrm{~s}, 1 \mathrm{H}), 4.19(\mathrm{q}, J=7.1$ $\mathrm{Hz}, 2 \mathrm{H}), 2.18$ (s, 3H), 2.13 (s, 3H), 2.05 (s, 3H), $1.40(\mathrm{~s}, 6 \mathrm{H}), 1.28$ $(\mathrm{t}, J=7.3 \mathrm{~Hz}, 3 \mathrm{H}) .{ }^{13} \mathrm{C}$ NMR $(\delta) 173.3,144.8,139.7,131.0,127.8$, $127.7,126.8,83.2,61.6,24.7,20.3,16.6,13.9$, 13.6. Anal. $\left(\mathrm{C}_{15} \mathrm{H}_{21} \mathrm{NO}_{5}\right) \mathrm{C}, \mathrm{H}, \mathrm{N}$.

2,2,5,7,8-Pentamethyl-2H-1,4-benzoxazin-3(4H)-one (21). To a solution of 2-methyl-2-(2,3,5-trimethyl-6-nitrophenoxy)propanoic acid ethyl ester (19) (0.45 g, $1.52 \mathrm{mmol})$ in dry ethanol (18.7 $\mathrm{mL}$ ) was added $10 \%$ palladium on carbon $(0.112 \mathrm{mg})$. The suspension was stirred under 1 atm of hydrogen gas at $70{ }^{\circ} \mathrm{C}$ for $24 \mathrm{~h}$. The reaction mixture was filtered through celite, the filtrate was concentrated in vacuo, and the crude product was purified by flash column chromatography (petroleum ether $40-60{ }^{\circ} \mathrm{C} /$ acetone $\left.(9: 1)\right)$ to afford compound 21 as a white solid, 0.283 g, $85 \%$ yield: $\mathrm{mp} 166-170{ }^{\circ} \mathrm{C} .{ }^{1} \mathrm{H}$ NMR $(\delta) 9.00(\mathrm{~s}, 1 \mathrm{H})$, $6.60(\mathrm{~s}, 1 \mathrm{H}), 2.22(\mathrm{~s}, 3 \mathrm{H}), 2.18(\mathrm{~s}, 3 \mathrm{H}), 2.11(\mathrm{~s}, 3 \mathrm{H}), 1.51(\mathrm{~s}$, $6 \mathrm{H}) .{ }^{13} \mathrm{C}$ NMR $(\delta) 170.1,140.4,132.0,124.5,123.2,122.8$, 119.5, 77. 3, 23.5, 19.4, 15.9, 11.3. MS, m/z: $219\left(100, \mathrm{M}^{+}\right)$. Anal. $\left(\mathrm{C}_{13} \mathrm{H}_{17} \mathrm{NO}_{2}\right) \mathrm{C}, \mathrm{H}, \mathrm{N}$.
6-Chloro-2,2,5,7,8-pentamethyl-2H-1,4-benzoxazin-3(4H)one (23). To a slurry of 2,2,5,7,8-pentamethyl-2 $H$-1,4-benzoxazin$3(4 H)$-one $(21)(0.13 \mathrm{~g}, 0.59 \mathrm{mmol})$ in petroleum ether $(10.5 \mathrm{~mL})$ was added a mixture of $\mathrm{AcOH} / \mathrm{H}_{2} \mathrm{O}_{2}(30 \%) / \mathrm{HCl}(37 \%)(0.22 \mathrm{~mL}$, $3.85 \mathrm{mmol} / 0.43 \mathrm{~mL}, 3.85 \mathrm{mmol} / 0.15 \mathrm{~mL}, 1.48 \mathrm{mmol})$ and the resulting mixture was refluxed for $48 \mathrm{~h}$. The reaction was diluted with ethyl acetate and the organic layer was extracted with water, saturated aqueous $\mathrm{NaHCO}_{3}$, brine, and was dried $\left(\mathrm{Na}_{2} \mathrm{SO}_{4}\right)$. The solvent was evaporated in vacuo and the residue was purified by flash column chromatrography (petroleum ether $40-60{ }^{\circ} \mathrm{C} / \mathrm{ethyl}$ acetate (9:1), to afford compound 23 as a white solid, $0.147 \mathrm{~g}$, 98\% yield; mp $234-237{ }^{\circ} \mathrm{C} .{ }^{1} \mathrm{H}$ NMR $(\delta) 8.33(\mathrm{~s}, 1 \mathrm{H}), 2.29(\mathrm{~s}$, $6 \mathrm{H}), 2.17$ (s, 3H), 1.49 (s, 6H). ${ }^{13} \mathrm{C}$ NMR $(\delta): 170.4,138.9,130.1$, $127.9,124.5,123.7,118.4,77.19,23.3,17.0,13.9,12.4$. MS, $m / z$ : $253\left(100, \mathrm{M}^{+}\right), 255$ (36). Anal. $\left(\mathrm{C}_{13} \mathrm{H}_{16} \mathrm{ClNO}_{2}\right) \mathrm{C}, \mathrm{H}, \mathrm{N}$.

2-(2,3,5-Trimethyl-6-nitrophenoxy)-2-phenylacetic Acid Methyl Ester (24). Following the procedure for 19, using 2-nitro-3,5,6trimethylphenol (17) $(0.4 \mathrm{~g}, 2.21 \mathrm{mmol})$, cesium carbonate (1.08 $\mathrm{g}, 3.31 \mathrm{mmol})$, bromophenylacetic acid methyl ester $(0.758 \mathrm{~g}, 3.31$ $\mathrm{mmol}$ ), and stirring at room temperature for $5 \mathrm{~min}$, compound 24 was obtained after purification by flash column chromatography (petroleum ether $40-60{ }^{\circ} \mathrm{C} /$ ethyl acetate (95:5)). Gummy solid, $0.88 \mathrm{~g}, 97 \%$ yield. ${ }^{1} \mathrm{H}$ NMR $(\delta) 7.45-7.33(\mathrm{~m}, 5 \mathrm{H}), 6.85(\mathrm{~s}, 1 \mathrm{H})$, $5.29(\mathrm{~s}, 1 \mathrm{H}), 3.69(\mathrm{~s}, 3 \mathrm{H}), 2.18(\mathrm{~s}, 3 \mathrm{H}), 2.17(\mathrm{~s}, 3 \mathrm{H}), 1.93(\mathrm{~s}, 3 \mathrm{H})$. ${ }^{13} \mathrm{C}$ NMR $(\delta) 169.7,147.5,144.3,140.9,135.2,129.3,128.7,127.9$, $127.8,127.5,84.6,52.5,20.2,17.0,13.2$. Anal. $\left(\mathrm{C}_{18} \mathrm{H}_{19} \mathrm{NO}_{5}\right) \mathrm{C}$, $\mathrm{H}, \mathrm{N}$.

2-Phenyl-5,7,8-trimethyl-2H-1,4-benzoxazin-3(4H)-one (25). To a solution of 2-(2,3,5-trimethyl-6-nitrophenoxy)-2-phenylacetic acid methyl ester (24) $(0.800 \mathrm{~g}, 2.43 \mathrm{mmol})$ in absolute ethanol $(12.1 \mathrm{~mL})$ at $0{ }^{\circ} \mathrm{C}$ was added $\mathrm{CuCl}(1.202 \mathrm{~g}, 12.15 \mathrm{mmol})$ followed by $\mathrm{NaBH}_{4}(0.918 \mathrm{~g}, 24.3 \mathrm{mmol})$ over $5 \mathrm{~min}$. The resulting mixture was refluxed for $15 \mathrm{~min}$, and the reaction was cooled to room temperature. Water was added and the mixture was extracted with ethyl acetate. The organic layer was washed with brine, dried over $\mathrm{Na}_{2} \mathrm{SO}_{4}$, and the solvent was evaporated in vacuo. The crude product was purified by flash column chromatography (petroleum ether $40-60{ }^{\circ} \mathrm{C} /$ acetone $\left.(9: 1)\right)$ to afford compound $\mathbf{2 5}$ as white crystals, $0.5 \mathrm{~g}, 77 \%$ yield; mp $171-173{ }^{\circ} \mathrm{C} .{ }^{1} \mathrm{H}$ NMR $(\delta) 9.23(\mathrm{~s}, 1 \mathrm{H})$, $7.33-7.48(\mathrm{~m}, 5 \mathrm{H}), 6.61(\mathrm{~s}, 1 \mathrm{H}), 5.72(\mathrm{~s}, 1 \mathrm{H}), 2.21(\mathrm{~s}, 9 \mathrm{H}) .{ }^{13} \mathrm{C}$ NMR $(\delta) 166.3,140.9,135.5,132.3,128.5,126.6,125.1,122.6$, 122.2, 120.9, 78.0, 19.4, 16.2, 11.6; MS, m/z: $267\left(10, \mathrm{M}^{+}\right), 207$ (100).

2-Phenyl-5,7,8-trimethyl-3,4-dihydro-2H-1,4-benzoxazine (36). To a solution of 2-phenyl-5,7,8-trimethyl-2H-1,4-benzoxazin-3(4H)one (25) $(0.2 \mathrm{~g}, 0.75 \mathrm{mmol})$ in THF $(35 \mathrm{~mL})$ was added dropwise at $0{ }^{\circ} \mathrm{C}$ a solution of boron trifluoride etherate $(2.24 \mathrm{mmol}, 0.28$ $\mathrm{mL}$ ). The reaction mixture was stirred at $0{ }^{\circ} \mathrm{C}$ for $20 \mathrm{~min}$, and subsequently $\mathrm{NaBH}_{4}(85 \mathrm{mg}, 2.24 \mathrm{mmol})$ was added over $10 \mathrm{~min}$. The resulting mixture was stirred at room temperature overnight and was diluted with ethyl acetate. The organic layer was extracted with saturated aqueous $\mathrm{NaHCO}_{3}$ and brine and was dried $\left(\mathrm{Na}_{2} \mathrm{SO}_{4}\right)$. The solvent was evaporated in vacuo, and the residue was purified by flash column chromatrography (petroleum ether $40-60{ }^{\circ} \mathrm{C} / \mathrm{ethyl}$ acetate $(9: 1)$ ), to afford benzoxazine $\mathbf{3 6}$ as white crystals, $0.186 \mathrm{~g}$, 98\% yield; mp 80-82 ${ }^{\circ} \mathrm{C} .{ }^{1} \mathrm{H}$ NMR $(\delta) 7.50-7.34(\mathrm{~m}, 5 \mathrm{H}), 6.59$ $(\mathrm{s}, 1 \mathrm{H}), 5.10(\mathrm{dd}, J=8.5 \mathrm{~Hz}, 2.4 \mathrm{~Hz}, 1 \mathrm{H}),, 3.61(\mathrm{~d}, J=11.6 \mathrm{~Hz}$, 1H), 3.36-3.29 (m, 1H), $2.23(\mathrm{~s}, 3 \mathrm{H}), 2.19(\mathrm{~s}, 3 \mathrm{H}), 2.15$ (s, 3H). ${ }^{13} \mathrm{C}$ NMR $(\delta) 142.5,139.7,128.5,128.4,128.0,126.8,129.1,123.3$, 122.4, 120.4, 75.5, 48.2,19.2, 16.6, 11.5. MS, $m / z: 253\left(100, \mathrm{M}^{+}\right)$. Anal. $\left(\mathrm{C}_{17} \mathrm{H}_{19} \mathrm{NO}\right) \mathrm{C}, \mathrm{H}, \mathrm{N}$.

2-Bromo-1-(5,7,8-trimethyl-2-phenyl-2,3-dihydro-1,4-benzoxazin-4-yl)-ethanone (43). To a solution of 2-phenyl-5,7,8-trimethyl3,4-dihydro- $2 H$-1,4-benzoxazine $(36)(150 \mathrm{mg}, 0.59 \mathrm{mmol})$ in dry dichloromethane $(12 \mathrm{~mL})$ was added dropwise at $0{ }^{\circ} \mathrm{C}$ triethylamine $(0.17 \mathrm{~mL}, 1.18 \mathrm{mmol})$ and bromoacetylbromide $(0.08 \mathrm{~mL}, 0.89$ $\mathrm{mmol})$. The resulting mixture was stirred at room temperature for $30 \mathrm{~min}$ and then diluted with saturated aqueous $\mathrm{NaHCO}_{3}$ and extracted with ethyl acetate. The organic phase was washed with saturated aqueous $\mathrm{NaCl}$ and was dried $\left(\mathrm{Na}_{2} \mathrm{SO}_{4}\right)$. The solvent was evaporated in vacuo, and the crude residue was purified by flash 
column chromatography (petroleum ether $40-60{ }^{\circ} \mathrm{C} / \mathrm{ethyl}$ acetate (9:1)) to afford compound $\mathbf{4 3}$ as a yellowish solid, $0.174 \mathrm{~g}, 79 \%$ yield; mp 109-111 ${ }^{\circ} \mathrm{C}$. Two rotamers of compound $\mathbf{4 3}$ were detected in the NMR spectra, and the corresponding peaks are defined by an asterisk. ${ }^{1} \mathrm{H}$ NMR $(\delta) 7.47-7.00(\mathrm{~m}, 5 \mathrm{H}), 6.69$ (bs, $1 \mathrm{H}), 5.73-4.88(\mathrm{~m}, 2 \mathrm{H}), 4.64-2.78(\mathrm{~m}, 3 \mathrm{H}), 2.28-2.10(\mathrm{~m}, 9 \mathrm{H})$. ${ }^{13} \mathrm{C}$ NMR $(\delta) 167.9,147.3,138.1,136.6,135.9 *, 128.8,128.7$, $128.6,128.5^{*}, 125.9,125.6^{*}, 125.5^{*}, 123.9,123.8^{*}, 122.8,78.1$, 51.6*, 48.6, 27.1, 26.3*, 19.9, 19.8*, 17.2, 11.7 .

Diethylamino-1-(5,7,8-trimethyl-2,3-dihydro-1,4-benzoxazin4-yl)-ethanone (46). Following the procedure for compound $\mathbf{1 5}$ using 2-bromo-1-(5,7,8-trimethyl-2,3-dihydro-1,4-benzoxazin-4-yl)ethanone (39) (83 mg, $0.28 \mathrm{mmol}$ ), compound 46 was obtained after purification of the crude residue by flash column chromatography (dichloromethane/methanol (95:5)). Viscous oil, $77 \mathrm{mg}, 95 \%$ yield. Two rotamers of compound $\mathbf{4 6}$ were detected in the NMR spectra and the corresponding peaks are defined by an asterisk. ${ }^{1} \mathrm{H}$ NMR $(\delta) 6.59 *$ and $6.58(1 \mathrm{H}), 4.90 *(\mathrm{ddd}, J=13.4 \mathrm{~Hz}, 4.3 \mathrm{~Hz}$, $1.2 \mathrm{~Hz}, 0.6 \mathrm{H})$ and $4.65(\mathrm{~d}, J=14.7 \mathrm{~Hz}, 0.4 \mathrm{H}), 4.49-4.19(\mathrm{~m}$, 2H), 3.49-3.09 (m, $2 \mathrm{H}$ and $0.4 \mathrm{H}), 2.80 *(\mathrm{ddd}, J=13.4 \mathrm{~Hz}, 4.3$ $\mathrm{Hz}, 4.3 \mathrm{~Hz}, 0.6 \mathrm{H}), 2.65-2.48$ (m, 4H), 2.20-2.04 (m, 9H), 1.05 $(\mathrm{t}, J=7.0 \mathrm{~Hz}, 2.4 \mathrm{H}), 0.89^{*}(\mathrm{t}, J=7.0 \mathrm{~Hz}, 3.6 \mathrm{H}) .{ }^{13} \mathrm{C} \mathrm{NMR}(\delta)$ 171.9, 168.9*, 146.9, 146.2*, 135.8, 135.1*, 131.3*, 129.3, 124.8, $123.5^{*}, 123.3,122.9^{*}, 122.3,121.5^{*}, 67.5^{*}, 67.2,57.8,53.0^{*}, 47.6$, 47.2*, 44.0*, 41.7, 19.8, 19.7*, 18.8*, 17.3, 12.1*, 11.5. MS (ESI) $m / z 291.3\left([\mathrm{M}+1]^{+}, 100\right)$. HRMS $\left(\mathrm{FAB}^{+}\right)$calcd for $\mathrm{C}_{17} \mathrm{H}_{27} \mathrm{O}_{2} \mathrm{~N}_{2}$ $[\mathrm{M}+1]^{+}$291.2073, found 291.2087. Anal. $\left(\mathrm{C}_{17} \mathrm{H}_{26} \mathrm{~N}_{2} \mathrm{O}_{2}\right) \mathrm{C}, \mathrm{H}$, N.

2-Diethylamino-1-(2,2,5,7,8-pentamethyl-2,3-dihydro-1,4-benzoxazin-4-yl)-ethanone (47). Following the procedure for compound 15 using 2-bromo-1-(2,2,5,7,8-pentamethyl-2,3-dihydro-1,4benzoxazin-4-yl)-ethanone (40) (90 mg, $0.28 \mathrm{mmol})$, compound 47 was obtained after purification of the crude residue by flash column chromatography (dichloromethane/methanol (96:4)). Viscous oil, $85 \mathrm{mg}$, $95 \%$ yield. Two rotamers of compound 47 were detected in the NMR spectra and the corresponding peaks are defined by an asterisk. ${ }^{1} \mathrm{H}$ NMR $(\delta) 6.62 *(\mathrm{~s}, 0.5 \mathrm{H}), 6.58(\mathrm{~s}, 0.5 \mathrm{H})$, $4.88^{*}(\mathrm{~d}, J=12.8 \mathrm{~Hz}, 0.5 \mathrm{H}), 4.45(\mathrm{~d}, J=14.0 \mathrm{~Hz}, 0.5 \mathrm{H})$, $3.73-3.15(\mathrm{~m}, 2 \mathrm{H}$ and $0.5 \mathrm{H}), 2.83-2.65(\mathrm{~m}, 4 \mathrm{H}), 2.59^{*}(\mathrm{~d}, J=$ $12.8 \mathrm{~Hz}, 0.5 \mathrm{H}), 2.21-2.04(\mathrm{~m}, 9 \mathrm{H}), 1.40-1.24(\mathrm{~m}, 6 \mathrm{H}), 1.11(\mathrm{t}$, $J=7.0 \mathrm{~Hz}, 3 \mathrm{H}), 1.00(\mathrm{t}, J=7.0 \mathrm{~Hz}, 3 \mathrm{H}) .{ }^{13} \mathrm{C} \mathrm{NMR}(\delta) 169.8$, $168.9^{*}, 148.3,146.2^{*}, 136.0,134.9 *, 130.5,128.5^{*}, 125.2,123.8$, $123.3^{*}, 123.1^{*}, 121.8,121.6^{*}, 80.1,76.2^{*}, 52.9,52.1^{*}, 47.7,47.5^{*}$, 27.5, 27.1*, 26.6, 25.0*, 19.7, 19.6, 19.3, 17.4, 11.7, 11.4. MS (ESI) $m / z 319.4\left([\mathrm{M}+1]^{+}, 100\right)$. HRMS $\left(\mathrm{FAB}^{+}\right)$calcd for $\mathrm{C}_{19} \mathrm{H}_{31} \mathrm{O}_{2} \mathrm{~N}_{2}$ $[\mathrm{M}+1]^{+}$319.2386, found 319.2380. Anal. $\left(\mathrm{C}_{19} \mathrm{H}_{30} \mathrm{~N}_{2} \mathrm{O}_{2}\right) \mathrm{C}, \mathrm{H}$, N.

1-(6-Chloro-5,7,8-trimethyl-2,3-dihydro-1,4-benzoxazin-4-yl)2-diethylamino-ethanone (48). Following the procedure for compound 15 using 2-bromo-1-(6-chloro-5,7,8-trimethyl-2,3-dihydro1,4-benzoxazin-4-yl)-ethanone (41) (93 mg, $0.28 \mathrm{mmol}$ ), compound 48 was obtained after purification of the crude residue by flash column chromatography (dichloromethane/methanol (98:2)). Viscous oil, $90 \mathrm{mg}$, quantitative yield). Two rotamers of compound 48 were detected in the NMR spectra and the corresponding peaks are defined by an asterisk. ${ }^{1} \mathrm{H}$ NMR $(\delta) 4.90^{*}(\mathrm{dd}, J=13.4 \mathrm{~Hz}$, $4.3 \mathrm{~Hz}, 0.6 \mathrm{H}), 4.64(\mathrm{dd}, J=13.7 \mathrm{~Hz}, 2.7 \mathrm{~Hz}, 0.4 \mathrm{H}), 4.56-4.17$ $(\mathrm{m}, 2 \mathrm{H}), 3.44-3.08(\mathrm{~m}, 2 \mathrm{H}$, and $0.4 \mathrm{H}), 2.78^{*}(\mathrm{ddd}, J=12.2 \mathrm{~Hz}$, $4.3 \mathrm{~Hz}, 4.3 \mathrm{~Hz}, 0.6 \mathrm{H}), 2.65-2.43(\mathrm{~m}, 4 \mathrm{H}), 2.30$ (s, 1.8H), 2.27 (s, $1.2 \mathrm{H}), 2.23(\mathrm{~s}, 1.8 \mathrm{H}), 2.14(\mathrm{~s}, 1.8 \mathrm{H}), 2.10(\mathrm{~s}, 1.2 \mathrm{H}), 2.09(\mathrm{~s}, 1.2 \mathrm{H})$, $1.04(\mathrm{t}, J=7.0 \mathrm{~Hz}, 2.4 \mathrm{H}), 0.87 *(\mathrm{t}, J=7.0 \mathrm{~Hz}, 3.6 \mathrm{H}) .{ }^{13} \mathrm{C} \mathrm{NMR}$ (d) $172.2,169.2^{*}, 145.4,144.8^{*}, 133.9,133.3^{*}, 129.8,128.2,126.7$, $126.4^{*}, 125.5,123.7,123.5^{*}, 122.9,67.5,67.1 *, 57.6^{*}, 53.5,47.6$, 47.2*, 43.9, 41.6, 17.3, 17.1, 16.7, 12.5, 12.2, 12.1, 11.4. MS (ESI) $\mathrm{m} / \mathrm{z} 325.3\left([\mathrm{M}+1]^{+}, 100\right), 327.3\left([\mathrm{M}+3]^{+}, 39\right)$. HRMS $\left(\mathrm{FAB}^{+}\right)$ calcd for $\mathrm{C}_{17} \mathrm{H}_{26} \mathrm{O}_{2} \mathrm{~N}_{2} \mathrm{Cl}[\mathrm{M}+1]^{+} 325.1683$, found 325.1686. Anal. $\left(\mathrm{C}_{17} \mathrm{H}_{25} \mathrm{ClN}_{2} \mathrm{O}_{2}\right) \mathrm{C}, \mathrm{H}, \mathrm{N}$.

1-(6-Chloro-2,2,5,7,8-pentamethyl-2,3-dihydro-1,4-benzoxazin4-yl)-2-diethylamino-ethanone (49). Following the procedure for compound 15 using 2-bromo-1-(6-chloro-2,2,5,7,8-pentamethyl-2,3dihydro-benzo[1,4]oxazin-4-yl)-ethanone (42) (103 mg, $0.28 \mathrm{mmol}$ ), compound 49 was obtained after purification of the crude residue by flash column chromatography (dichloromethane/methanol (96: 4)). Viscous oil, $92 \mathrm{mg}, 93 \%$ yield. Two rotamers of compound 49 were detected in the NMR spectra, and the corresponding peaks are defined by an asterisk. ${ }^{1} \mathrm{H}$ NMR $(\delta) 4.91 *(\mathrm{~d}, J=12.8 \mathrm{~Hz}, 0.6$ $\mathrm{H}), 4.55(\mathrm{~d}, J=14.0 \mathrm{~Hz}, 0.4 \mathrm{H}), 3.63(\mathrm{~d}, J=14.6 \mathrm{~Hz}, 0.4 \mathrm{H})$, $3.37-3.10(\mathrm{~m}, 2 \mathrm{H}), 2.83-2.54(\mathrm{~m}, 4 \mathrm{H}$ and $0.6 \mathrm{H}), 2.32-2.10(\mathrm{~m}$, $9 \mathrm{H}), 1.40-1.24(\mathrm{~m}, 6 \mathrm{H}), 1.08(\mathrm{t}, J=7.3 \mathrm{~Hz}, 2.4 \mathrm{H}), 0.92 *(\mathrm{t}, J=$ 7.0 Hz, 3.6H). ${ }^{13} \mathrm{C}$ NMR $(\delta) 171.1,170.0^{*}, 146.8,144.9^{*}, 133.8$, 133.0*, 129.1, 127.6* $126.9,126.2^{*}, 126.1,124.5^{*}, 123.1,122.5^{*}$, $80.4,76.5^{*}, 57.3,53.5^{*}, 52.9,51.8^{*}, 47.4,27.3,27.0,26.5,25.1$, $17.7,17.1,16.9,12.5,12.3,12.2,11.8$. MS (ESI) $m / z 353.3([\mathrm{M}+$ $\left.1]^{+}, 100\right), 355.3\left([\mathrm{M}+3]^{+}, 37\right)$. HRMS $\left(\mathrm{FAB}^{+}\right)$calcd for $\mathrm{C}_{19} \mathrm{H}_{30} \mathrm{O}_{2} \mathrm{~N}_{2} \mathrm{Cl}[\mathrm{M}+1]^{+}$353.1996, found 353.2001. Anal. $\left(\mathrm{C}_{19} \mathrm{H}_{29} \mathrm{ClN}_{2} \mathrm{O}_{2}\right) \mathrm{C}, \mathrm{H}, \mathrm{N}$.

2-Diethylamino-1-(5,7,8-trimethyl-2-phenyl-2,3-dihydro-1,4benzoxazin-4-yl)-ethanone (50). Following the procedure for compound 15 using 2-bromo-1-(5,7,8-trimethyl-2-phenyl-2,3-dihydro-1,4-benzoxazin-4-yl)-ethanone (43) (104 mg, $0.28 \mathrm{mmol})$, compound 50 was obtained after purification of the crude residue by flash column chromatography (dichloromethane/methanol (98: 2)). Viscous oil, $98 \mathrm{mg}, 95 \%$ yield. Two rotamers of compound 50 were detected in the NMR spectra and the corresponding peaks are defined by an asterisk. ${ }^{1} \mathrm{H}$ NMR $(\delta) 7.43-7.23(\mathrm{~m}, 5 \mathrm{H}), 6.67$ (bs, 1H), 5.67-4.78 (m, 2H), 3.72-2.43 (m, 7H), 2.27-2.08 (m., 9H), $1.11-0.83(\mathrm{~m}, 6 \mathrm{H}) .{ }^{13} \mathrm{C} \mathrm{NMR}(\delta) 172.3,168.5^{*}, 147.2,146.6^{*}$, $140.8^{*}, 138.7,136.0,135.3^{*}, 131.3,129.3^{*}, 128.7,128.6,128.3$, $125.8,125.7,124.7,123.6,123.5^{*}, 122.5,122.4^{*}, 121.7,79.2^{*}$, $79.0,58.2,53.2,50.6,48.4,47.7,47.5,47.3^{*}, 19.8,19.7^{*}, 18.9$, 17.4, 12.2, 11.9*, 11.7, 11.4*. MS (ESI) $\mathrm{m} / \mathrm{z} 367.4\left([\mathrm{M}+1]^{+}\right.$, 100); HRMS $\left(\mathrm{FAB}^{+}\right.$) calcd for $\mathrm{C}_{23} \mathrm{H}_{31} \mathrm{O}_{2} \mathrm{~N}_{2}[\mathrm{M}+1]^{+}$367.2386, found 367.2370. Anal. $\left(\mathrm{C}_{23} \mathrm{H}_{30} \mathrm{~N}_{2} \mathrm{O}_{2}\right) \mathrm{C}, \mathrm{H}, \mathrm{N}$.

1-(6-Chloro-5,7,8-trimethyl-2-phenyl-2,3-dihydro-1,4-benzoxazin-4-yl)-2-diethylamino-ethanone (51). Following the procedure for compound 15 using 2-bromo-1-(6-chloro-5,7,8-trimethyl-2phenyl-2,3-dihydro-1,4-benzoxazin-4-yl)-ethanone (44) (114 mg, $0.28 \mathrm{mmol}$ ), compound $\mathbf{5 1}$ was obtained after purification of the crude residue by flash column chromatography (dichloromethane/ methanol (98:2)). Viscous oil, $109 \mathrm{mg}$, 97\% yield. Two rotamers of compound $\mathbf{5 1}$ were detected in the NMR spectra and the corresponding peaks are defined by an asterisk. ${ }^{1} \mathrm{H}$ NMR $(\delta)$ 7.41-7.21 (m, 5H), 5.67-4.80 (m, 2H), 3.71-2.03 (m, 16H), 1.13-0.82 (m, 6H). ${ }^{13} \mathrm{C}$ NMR $(\delta)$ 172.4, 170.3, 168.7, 145.8, 145.5, $145.3,140.6,138.4,134.1,133.5,133.3,129.9,129.7,128.7,128.6$, 128.4, 127.0, 126.7, 125.8, 125.7, 125.4, 124.2, 123.8, 123.2, 123.0, $122.8,79.3,79.0 *, 58.0,56.5,53.6,50.5,48.9,48.3^{*}, 47.6,47.5$, 47.3, 17.5, 17.2, 16.9, 12.7, 12.3, 11.9, 11.3. MS (ESI) $\mathrm{m} / \mathrm{z} 401.3$ $\left([\mathrm{M}+1]^{+}, 100\right), 403.4\left([\mathrm{M}+3]^{+}, 37\right)$. HRMS $\left(\mathrm{FAB}^{+}\right)$calcd for $\mathrm{C}_{23} \mathrm{H}_{30} \mathrm{O}_{2} \mathrm{~N}_{2} \mathrm{Cl}[\mathrm{M}+1]^{+}$401.1996, found 401.1968. Anal. $\left(\mathrm{C}_{23} \mathrm{H}_{29} \mathrm{ClN}_{2} \mathrm{O}_{2}\right) \mathrm{C}, \mathrm{H}, \mathrm{N}$.

1-(6-Methoxy-5,7,8-trimethyl-2-phenyl-2,3-dihydro-1,4-benzoxazin-4-yl)-2-diethylamino-ethanone (52). Following the procedure for compound 15 using 2-bromo-1-(6-methoxy-5,7,8trimethyl-2-phenyl-2,3-dihydro-1,4-benzoxazin-4-yl)-ethanone (45) (120 mg, $0.28 \mathrm{mmol}$ ), compound $\mathbf{5 2}$ was obtained after purification of the crude residue by flash column chromatography (dichloromethane/methanol (98:2)). Viscous oil, $0.105 \mathrm{~g}$, 95\% yield); Two rotamers of compound $\mathbf{5 2}$ were detected in the NMR spectra, and the corresponding peaks are defined by an asterisk. ${ }^{1} \mathrm{H}$ NMR $(\delta)$ $7.43-7.21(\mathrm{~m}, 5 \mathrm{H}), 5.65-4.75(\mathrm{~m}, 2 \mathrm{H}), 3.69(\mathrm{~s}, 3 \mathrm{H}), 3.68-2.38$ $(\mathrm{m}, 7 \mathrm{H}), 2.28-2.04(\mathrm{~m}, 9 \mathrm{H}), 1.12-0.82(\mathrm{~m}, 6 \mathrm{H}) .{ }^{13} \mathrm{C}$ NMR $(\delta)$ $172.3^{*}, 168.4,150.5^{*}, 150.0,143.8^{*}, 143.1,138.7,129.1,128.7$, $128.5,128.2,125.8,125.7,124.8,124.6,123.3,122.9,122.8,122.5$, 122.1, 79.0, 78.9*, 77.8*, 60.2, 58.1, 56.6, 53.3, 50.7, 49.1, 48.4, $47.5,47.4,47.2,12.7,12.5,12.3,12.1,12.0,11.3$. MS (ESI) $\mathrm{m} / \mathrm{z}$ $397.4\left([\mathrm{M}+1]^{+}, 100\right)$. HRMS $\left(\mathrm{FAB}^{+}\right)$calcd for $\mathrm{C}_{24} \mathrm{H}_{33} \mathrm{O}_{3} \mathrm{~N}_{2}[\mathrm{M}$ $+1]^{+}$397.2491, found 397.2512. Anal. $\left(\mathrm{C}_{24} \mathrm{H}_{32} \mathrm{~N}_{2} \mathrm{O}_{3}\right) \mathrm{C}, \mathrm{H}, \mathrm{N}$.

2-(2,3,5-Trimethyl-6-nitrophenoxy)-2-methylmalonic Acid Diethyl Ester (53). Following the procedure for compound 19 using 2-nitro-3,5,6-trimethylphenol (17) (0.4 g, $2.21 \mathrm{mmol})$ in dry DMF $(7.35 \mathrm{~mL})$, cesium carbonate $(1.44 \mathrm{~g}, 4.42 \mathrm{mmol})$, TBAI (catalytic 
amount), and 2-bromo-2-methyl-malonic acid diethyl ester (0.84 $\mathrm{mL}, 4.42 \mathrm{mmol}$ ) after purification by flash column chromatography (petroleum ether $40-60{ }^{\circ} \mathrm{C} /$ diethyl ether (9:1)), we obtained compound $\mathbf{5 3}$ as a viscous oil $0.748 \mathrm{~g}, 96 \%$ yield. ${ }^{1} \mathrm{H}$ NMR $(\delta)$ $6.71(\mathrm{~s}, 1 \mathrm{H}), 4.09(\mathrm{q}, J=7.1 \mathrm{~Hz}, 4 \mathrm{H}), 2.05(\mathrm{~s}, 3 \mathrm{H}), 1.97(\mathrm{~s}, 3 \mathrm{H})$, $1.93(\mathrm{~s}, 3 \mathrm{H}), 1.32(\mathrm{~s}, 3 \mathrm{H}), 1.12(\mathrm{t}, J=7.3 \mathrm{~Hz}, 6 \mathrm{H}) .{ }^{13} \mathrm{C} \mathrm{NMR}(\delta)$ : $167.9,145.8,143.1,139.9,131.1,128.2,126.5,84.4,61.9,19.6$, 17.7, 17.6, 15.9, 13.4, 12.7. MS, $m / z: 353\left(8, \mathrm{M}^{+}\right), 205$ (100). Anal. $\left(\mathrm{C}_{17} \mathrm{H}_{23} \mathrm{NO}_{7}\right) \mathrm{C}, \mathrm{H}, \mathrm{N}$.

2,5,7,8-Tetramethyl-3-oxo-3,4-dihydro-2H-1,4-benzoxazine2-carboxylic Acid Ethyl Ester (54). Following the procedure for compound 21 using 2-(2,3,5-trimethyl-6-nitrophenoxy)-2-methylmalonic acid diethyl ester (53) $(0.7 \mathrm{~g}, 1.98 \mathrm{mmol})$ and $\mathrm{Pd} / \mathrm{C}(0.175$ g) after purification by flash column chromatography (petroleum ether $40-60{ }^{\circ} \mathrm{C} /$ ethyl acetate $(85: 15)$ ), we obtained compound 54 as white crystals, $0.444 \mathrm{~g}, 81 \%$ yield; mp $124-126{ }^{\circ} \mathrm{C}$. ${ }^{1} \mathrm{H}$ NMR (d) $8.15(\mathrm{~s}, 1 \mathrm{H}), 6.62(\mathrm{~s}, 1 \mathrm{H}), 4.20-4.03(\mathrm{~m}, 2 \mathrm{H}), 2.19(\mathrm{~s}, 3 \mathrm{H})$, $2.18(\mathrm{~s}, 3 \mathrm{H}), 2.17(\mathrm{~s}, 3 \mathrm{H}), 1.85(\mathrm{~s}, 3 \mathrm{H}), 1.13(\mathrm{t}, J=7.3 \mathrm{~Hz}, 3 \mathrm{H})$. ${ }^{13} \mathrm{C}$ NMR $(\delta) 168.9,164.7,141.2,132.3,125.5,123.3,122.3,120.3$, 80.5, 62.0, 20.5, 19.3, 15.9, 13.8, 11.4. MS, $m / z: 277\left(61, \mathrm{M}^{+}\right)$, 204 (100). Anal. $\left(\mathrm{C}_{15} \mathrm{H}_{19} \mathrm{NO}_{4}\right) \mathrm{C}, \mathrm{H}, \mathrm{N}$.

2,5,7,8-Tetramethyl-3-thioxo-3,4-dihydro-2H-1,4-benzoxazine2-carboxylic Acid Ethyl Ester (56). A mixture of 2,5,7,8tetramethyl-3-oxo-3,4-dihydro-2H-1,4-benzoxazine-2-carboxylic acid ethyl ester (54) (0.2 g, $0.72 \mathrm{mmol})$, Lawesson's reagent $(0.32 \mathrm{~g}$, $0.79 \mathrm{mmol})$, and toluene $(0.81 \mathrm{~mL})$ was refluxed under inert atmosphere for $2 \mathrm{~h}$. The resulting mixture was mixed with silica gel and the toluene was evaporated in vacuo. The silica gel cake was then added to a column of silica gel, and the column was eluted with petroleum ether $40-60{ }^{\circ} \mathrm{C} / e$ thyl acetate (85:15) to afford compound 56 as a green-yellow solid $(0.205$ g, yield: $97 \%) ; \mathrm{mp}$ 114-116 ${ }^{\circ} \mathrm{C} .{ }^{1} \mathrm{H}$ NMR $(\delta) 9.45(\mathrm{~s}, 1 \mathrm{H}), 6.59$ (s, 1H,), 4.21-4.05 $(\mathrm{m}, 2 \mathrm{H}), 2.22(\mathrm{~s}, 3 \mathrm{H}), 2.17(\mathrm{~s}, 3 \mathrm{H}), 2.15(\mathrm{~s}, 3 \mathrm{H}), 1.95(\mathrm{~s}, 3 \mathrm{H}), 1.13$ $(\mathrm{t}, J=7.0 \mathrm{~Hz}, 3 \mathrm{H}) .{ }^{13} \mathrm{C}$ NMR $(\delta) 191.5,168.6,142.5,134.4,125.2$, $123.4,122.2,119.5,83.9,62.2,23.8,19.6,15.9,13.8,11.2$. MS, $m / z: 293\left(10, \mathrm{M}^{+}\right), 220$ (100). Anal. $\left(\mathrm{C}_{15} \mathrm{H}_{19} \mathrm{NO}_{3} \mathrm{~S}\right) \mathrm{C}, \mathrm{H}, \mathrm{N}$.

2,5,7,8-Tetramethyl-3,4-dihydro-2H-1,4-benzoxazine-2-carboxylic Acid Ethyl Ester (58). To a solution of 2,5,7,8-tetramethyl3-thioxo-3,4-dihydro-2H-1,4-benzoxazine-2-carboxylic acid ethyl ester (56) $(0.2 \mathrm{~g}, 0.68 \mathrm{mmol})$ in tetrahydrofuran $(1 \mathrm{~mL})$ and ethanol $(1 \mathrm{~mL})$ was added Raney nickel and water $(0.5 \mathrm{~mL})$. After stirring for $5 \mathrm{~min}$, an additional amount of catalyst was added and water $(0.5 \mathrm{~mL})$ and the reaction was stirred at room temperature for additional $15 \mathrm{~min}$. The reaction mixture was diluted with ethyl acetate, it was filtered through celite, and the solvent was evaporated in vacuo. The residue was purified by flash column chromatography petroleum ether $40-60{ }^{\circ} \mathrm{C} /$ ethyl acetate $(90: 10)$ to afford compound 58 as white crystals $(0.146 \mathrm{~g}, 82 \%)$; mp $84-87{ }^{\circ} \mathrm{C} .{ }^{1} \mathrm{H}$ NMR $(\delta)$ $6.49(\mathrm{~s}, 1 \mathrm{H}), 4.13(\mathrm{q}, J=7.1 \mathrm{~Hz}, 2 \mathrm{H}), 3.75(\mathrm{~d}, J=11.6 \mathrm{~Hz}, 1 \mathrm{H})$, $3.14(\mathrm{~d}, J=11.6 \mathrm{~Hz}, 1 \mathrm{H}), 2.16(\mathrm{~s}, 3 \mathrm{H}), 2.15(\mathrm{~s}, 3 \mathrm{H}), 2.05(\mathrm{~s}, 3 \mathrm{H})$, $1.56(\mathrm{~s}, 3 \mathrm{H}), 1.17(\mathrm{t}, J=7.0 \mathrm{~Hz}, 3 \mathrm{H}) .{ }^{13} \mathrm{C} \mathrm{NMR}(\delta) 172.5,141.0$, 127.7, 126.7, 123.4, 122.1, 120.2, 76.4, 61.2, 48.2, 22.6, 19.3, 16.4, 14.0, 11.4. MS, $m / z: 263\left(100, \mathrm{M}^{+}\right)$; Anal. $\left(\mathrm{C}_{15} \mathrm{H}_{21} \mathrm{NO}_{3}\right) \mathrm{C}, \mathrm{H}, \mathrm{N}$.

4-(2-Bromo-acetyl)-2,5,7,8-tetramethyl-3,4-dihydro-2H-1,4benzoxazine-2-carboxylic Acid Ethyl Ester (60). Following the procedure for compound $\mathbf{4 3}$ using 2,5,7,8-tetramethyl-3,4-dihydro$2 \mathrm{H}$-1,4-benzoxazine-2-carboxylic acid ethyl ester (58) (156 mg, 0.59 $\mathrm{mmol}$ ), compound $\mathbf{6 0}$ was obtained after purification of the crude residue by flash column chromatography (petroleum ether 40-60 ${ }^{\circ} \mathrm{C} /$ dichloromethane/ethyl acetate (80:15/5)). Yellowish solid, 0.201 g, $89 \%$ yield; $\mathrm{mp} 112-114{ }^{\circ} \mathrm{C}$. The NMR spectra contain multiple signals due to the presence of rotamers. ${ }^{1} \mathrm{H}$ NMR $(\delta) 6.69-6.63$ $(\mathrm{m}, 1 \mathrm{H}), 5.22-4.48(\mathrm{~m}, 1 \mathrm{H}), 4.19-3.75(\mathrm{~m}, 4 \mathrm{H}), 2.22-2.13(\mathrm{~m}$, $9 \mathrm{H}), 1.71-1.60(\mathrm{~m}, 3 \mathrm{H}), 1.32-1.14(\mathrm{~m}, 3 \mathrm{H}) .{ }^{13} \mathrm{C} \mathrm{NMR}(\delta) 172.8$, 171.6, 167.5, 167.2, 165.5, 148.5, 146.4, 145.1, 136.9, 136.3, 135.2, $130.8,128.7,128.0,126.2,124.9,124.2,124.0,122.8,122.7,121.6$, $120.5,82.1,79.5,78.9,62.4,62.2,61.6,50.9,49.5,49.1,27.9,27.0$, $26.4,24.3,22.8,22.3,19.8,19.6,18.2,17.3,16.9,14.0,11.5,11.4$. Anal. $\left(\mathrm{C}_{17} \mathrm{H}_{22} \mathrm{BrNO}_{4}\right) \mathrm{C}, \mathrm{H}, \mathrm{N}$.
4-(2-Diethylamino-acetyl)-2,5,7,8-tetramethyl-3,4-dihydro- $2 \mathrm{H}$ 1,4-benzoxazine-2-carboxylic Acid Ethyl Ester (62). Following the procedure for compound 15 using 4-(2-bromo-acetyl)-2,5,7,8tetramethyl-3,4-dihydro-2 $\mathrm{H}$-1,4-benzoxazine-2-carboxylic acid ethyl ester (60) (109 mg, $0.28 \mathrm{mmol}$ ), compound 62 was obtained after purification of the crude residue by flash column chromatography (dichloromethane/ethyl acetate (6:4)). Viscous oil, $85 \mathrm{mg}, 81 \%$ yield. The NMR spectra contain multiple signals due to the presence of rotamers. ${ }^{1} \mathrm{H}$ NMR $(\delta) 6.68-6.61(\mathrm{~m}, 1 \mathrm{H}), 5.32-5.06(\mathrm{~m}, 1 \mathrm{H})$, 4.21-4.02 (m, 2H), 3.74-2.41 (m, 7H), 2.22-2.03 (m, 9H), 1.69-1.55 (m, 3H) $1.33-0.89(\mathrm{~m}, 9 \mathrm{H}) .{ }^{13} \mathrm{C} \mathrm{NMR}(\delta): 173.0,172.2$, 172.0, 171.9, 171.6, 169.9, 148.7, 146.6, 145.3, 136.3, 135.8, 134.6, $130.5,128.9,128.7,127.3,124.9,124.0,123.9,122.6,121.7,121.5$, $82.4,80.1,79.2,62.1,61.7,61.5,57.7,57.5,53.6,53.1,50.3,50.0$, 49.4, 49.3, 47.6, 47.4, 24.7, 23.0, 22.9, 19.8, 19.6, 19.4, 17.5, 17.1, $14.0,13.9,12.3,12.2,11.8,11.6,11.5$. MS (ESI) $\mathrm{m} / \mathrm{z} 377.4([\mathrm{M}+$ $\left.1]^{+}, 100\right)$. HRMS $\left(\mathrm{FAB}^{+}\right.$) calcd for $\mathrm{C}_{21} \mathrm{H}_{33} \mathrm{O}_{4} \mathrm{~N}_{2}[\mathrm{M}+1]^{+} 377.2440$, found 377.2441. Anal. $\left(\mathrm{C}_{21} \mathrm{H}_{32} \mathrm{~N}_{2} \mathrm{O}_{4}\right) \mathrm{C}, \mathrm{H}, \mathrm{N}$.

Animals and Heart Preparations. Male Wistar rats weighing about 300-350 g were housed under controlled light (12 L/12D) and temperature with free access to food and water in compliance with the prescriptions for the care and use of laboratory animals. Rats were anesthetized with pentobarbital (30-40 mg per animal). After intravenous administration of heparin, the chests were opened and the hearts were rapidly excised and mounted on a nonrecirculating Langendorff perfusion apparatus. Retrogade perfusion was established at a pressure of $90 \mathrm{~cm} \mathrm{H}_{2} \mathrm{O}$ with an oxygenated normothermic Krebs-Hensleit bicarbonate (KHB) buffer $(25 \mathrm{mmol}$ $1^{-1} \mathrm{NaHCO}_{3}, 118 \mathrm{mmol} \mathrm{l}^{-1} \mathrm{NaCl}, 2.5 \mathrm{mmol} \mathrm{l}^{-1} \mathrm{CaCl}_{2}, 4.7 \mathrm{mmol}$ $1^{-1} \mathrm{KCl}, 1.4 \mathrm{mmol} \mathrm{l}^{-1} \mathrm{MgSO}_{4}, 1.2 \mathrm{mmol} \mathrm{l}^{-1} \mathrm{KH}_{2} \mathrm{PO}_{4}$, pH 7.2 at $25^{\circ} \mathrm{C}$ ) supplemented with $11 \mathrm{mmol} \mathrm{l}^{-1}$ glucose and equilibrated with $95 \% \mathrm{O}_{2} / 5 \% \mathrm{CO}_{2}$. The temperature of the hearts and perfusates was maintained at $37^{\circ} \mathrm{C}$ by the use of a water-jacketed apparatus. All hearts were equilibrated for 20 min under these conditions. At the end of the equilibration period, hearts were made ischemic for 15 min by perfusing them with the ischemic KHB (KHB with Tris$\mathrm{HCl} 10 \mathrm{mM}$ instead of glucose and equilibrated with $\mathrm{N}_{2}$ before use) followed by $60 \mathrm{~min}$ of reperfusion. The compounds were present during the last $5 \mathrm{~min}$ of ischemia and during reperfusion at a final concentration of $2 \mu \mathrm{M}$.

Evaluation of Antiarrhythmic Activity. Electrocardiograms were recorded during equilibration, ischemia, and reperfusion. Arrhythmia scores (AS) were calculated for the first $10 \mathrm{~min}$ of reperfusion according to the Lambeth Convention Guidelines. ${ }^{41}$

Evaluation of Antioxidant Activity. At the end of the perfusions, hearts were "freeze-clamped" between aluminum tongs, cooled in liquid $\mathrm{N}_{2}$, and after the removal of the atria, the ventricles were pulverized under liquid $\mathrm{N}_{2}$ and powders were stored at -80 ${ }^{\circ} \mathrm{C}$. A portion of the tissue powder was analyzed for malondialdehyde (MDA) content by using the thiobarbituric acid assay. ${ }^{43}$ To prevent auto-oxidation of the samples, homogenization was carried out at $4{ }^{\circ} \mathrm{C}$ in nitrogen equilibrated solution in the presence of $0.04 \%$ butylated hydroxytoluene, $1.6 \%$ ethanol. The values were expressed as nanomoles of TBA reactive substances (MDA equivalent) per gram of tissue. 1,1,3,3-Tetraethoxypropane $(0,0.5,1.0,2.0,4.0,8.0$ and $16.0 \mathrm{nmol})$ served as external standard. Results are expressed as mean \pm SEM. Differences between groups were assessed by Student's unpaired and ANOVA $t$ tests and considered significant when $p<0,05$.

Conventional Microelectrode Technique. New Zealand rabbits weighing $1.5-2.0 \mathrm{~kg}$ of either sex were used. Each animal was sacrificed by cervical dislocation after an intravenous injection of $400 \mathrm{IU} \mathrm{kg} / \mathrm{L}$ heparin. The chest was opened, the heart quickly removed, and immediately rinsed in oxygenated modified Locke's solution containing (in $\mathrm{mM}$ ): $\mathrm{NaCl}, 120 ; \mathrm{KCl}, 4 ; \mathrm{CaCl}_{2}, 1.0 ; \mathrm{MgCl}_{2}$, $1 ; \mathrm{NaHCO}_{3}, 22$ and glucose, 11 . The $\mathrm{pH}$ of this solution was 7.35 to 7.40 when saturated with $95 \% \mathrm{O}_{2}$ and $5 \% \mathrm{CO}_{2}$ at $37^{\circ} \mathrm{C}$. Tips of papillary muscles obtained from the right ventricle were individually mounted in a tissue chamber (volume $\approx 50 \mathrm{~mL}$ ). Each ventricular preparation was initially stimulated at a basic cycle length of 1000 ms (frequency $=1 \mathrm{~Hz}$ ), using rectangular constant current pulses 
$1 \mathrm{~ms}$ in duration. These stimuli were isolated from ground and delivered through a bipolar platinum electrode in contact with the preparation. Temperature of the superfusate was kept constant at $37^{\circ} \mathrm{C}$. Transmembrane potentials were recorded using conventional microelectrode techniques. Microelectrodes filled with $3 \mathrm{M} \mathrm{KCl}$ and having tip resistances of 5-20 M $\Omega$ were connected to the input of a high impedance electrometer (Experimetria). The voltage output of the amplifier was displayed on a memory oscilloscope (Tektronix $2230100 \mathrm{MHz}$ digital storage oscilloscope, Beaverton, OR) and fed into a computer (PC, Windows XP) at a sampling rate of 10 $\mathrm{kHz}$. The stimulation triggering and data acquisition were governed by homemade (APES)/software. The resting membrane potential (RP), conduction time (CT), action potential amplitude (APA), maximal rate of depolarization $\left(V_{\max }\right)$, and action potential duration at 50 and $90 \%$ of (APD50/90) were automatically measured using the software and analyzed both online and off-line. In each experiment, baseline action potential characteristics were first determined during continuous pacing at $1 \mathrm{~Hz}$, and then pacing cycle length was sequentially varied between 300 and $5000 \mathrm{~ms}$. The 25 th action potential was measured at each cycle length, and the cycle length was then changed so that "quasi" steady-state frequency response relations could be generated rapidly. At least $1 \mathrm{~h}$ was allowed for each preparation to equilibrate after mounting before experimental measurements were initiated.

Acknowledgment. This work was supported in part by the Greek General Secretariat for Research and Technology, "Excellence in the Research Institutes Supervised by the GSRT" EPAN 3.3.1. (2006-2009), by the Hungarian Academy of Sciences, and by grants from the Hungarian National Research Foundation (OTKA NI-61902) and the Hungarian Ministry of Health (ETT-360/2006).

Supporting Information Available: Experimental procedures and spectroscopic data for compounds $1,2,4,5,7,8,10,11,13$, $14,18,20,22,26-35,37-42,44,45,55,57,59,61,63-65,26 \mathrm{~b}$, 37b, and 51b. Effect of compounds 46, 47, 49, 50, 62, and 63 and reference drugs sotalol and mexiletine on the action potential in rabbit right ventricular papillary muscles (Figure A). Elemental analysis data for compounds $13-15,17-19,21-26,30,31,36-38$, and 44-63. This material is available free of charge via the Internet at http://pubs.acs.org.

\section{References}

(1) Janse, M. J.; Wit, A. L. Electrophysiological mechanisms of ventricular arrhythmias resulting from myocardial ischemia and infarction. Physiol. Rev. 1989, 69, 1049-1169.

(2) (a) The Cardiac Arrhythmia Suppression Trial (CAST) Investigators. Preliminary Report: Effect of Encainide and Flecainide on Mortality in a Randomized Trial of Arrhythmia Suppression after Myocardial Infarction. N. Engl. J. Med. 1989, 321, 406-412; (b) The Cardiac Arrhythmia Suppression Trial II Investigators. Effect of the antiarrhythmic agent moricizine on survival after myocardial infarction. N. Engl. J. Med., 1992, 327, 227-233.

(3) Zareba, W. Implantable cardioverter defibrillator therapy in postinfarction patients. Curr. Opin. Cardiol. 2004, 19, 619-624.

(4) (a) Piper, H. M.; Garcia-Dorado, D.; Ovize, M. A. fresh look at reperfusion injury. Cardiovasc. Res. 1998, 38, 291-300. (b) Andreadou, I.; Iliodromitis, E. K.; Koufaki, M.; Farmakis, D.; Tsotinis, A.; Kremastinos, D. Th. Alternative Pharmacological Interventions that Limit Myocardial Infarction. Curr. Med. Chem. 2008, 15, 3204 3213.

(5) Ambrosio, G.; Tritto, I. Reperfusion injury: experimental evidence and clinical implications. Am. Heart J. 1999, 138, S69-S75.

(6) (a) Park, J. L.; Lucchesi, B. R. Mechanisms of myocardial reperfusion injury. Ann. Thorac. Surg. 1999, 68, 1905-1912. (b) Yellon, D. M.; Hausenloy, D. J. Myocardial Reperfusion Injury. N. Engl. J. Med. 2007, 357, 1121-1135.

(7) (a) Piper, H. M.; Meuter, K.; Schäfer, C. Cellular mechanisms of ischemia-reperfusion injury. Ann. Thorac. Surg. 2003, 75, S644-S648. (b) Woodcock, E. A. Roles of alpha1A- and alpha1B-adrenoceptors in heart: insights from studies of genetically modified mice. Clin. Exp. Pharmacol. Physiol. 2007, 34, 884-888. (c) Vasilevski, O.; Grubb, D. R.; Filtz, T. M.; Yang, S.; McLeod-Dryden, T. J.; Luo, J.; Karna, D.; Chen, J.; Woodcock, E. A. Ins $(1,4,5) \mathrm{P}(3)$ regulates phospholipase
C $\beta 1$ expression in cardiomyocytes. J. Mol. Cell. Cardiol. 2008, 45 , 679-684.

(8) (a) Wang, Q. D.; Pernow, J.; Sjoquist, P. O.; Ryden, L. Pharmacological possibilities for protection against myocardial reperfusion injury. Cardiovasc. Res. 2002, 55, 25-37. (b) Grover, G. J.; Garlid, K. D. ATP-Sensitive Potassium Channels: A Review of their Cardioprotective Pharmacology. J. Mol. Cell. Cardiol. 2000, 32, 677-695.

(9) Parrat, J. R. Inhibitors of the slow calcium current and early ventricular arrhythmias In: Parratt, J. R., Ed.; Early Arrhythmias Resulting from Myocardial Ischemia; Macmillan: London, 1982, 329-346.

(10) He, Z. S.; Komori, S.; Tamura, K.; Hashimoto, K. Inhibitory effect of moricizine on reperfusion induced tachyarrhythmias in rats. A comparison study with disopyramide and mexiletine. Jpn. Circ. J. 1992, 56, 861-865.

(11) Corr, P. B.; Pogwizd, S. M. Mechanisms contributing to arrhythmogenesis during early myocardial ischemia, subsequent reperfusion, and chronic infarction. Angiology 1988, 39, 684-699.

(12) Komori, S.; Sano, S.; Li, B. H.; Matsumara, K.; Naitoh, A.; Mochizuki, S.; Ishihara, T.; Watanabe, A.; Umetani, K.; Iiiri, H.; Hashimoto, K.; Tamura, K. Effects of bidisomide (SC-40230), a new class I antiarrhythmic agent, on ventricular arrhythmias induced by coronary artery occlusion and reperfusion in anesthetized rats; comparison with mexiletine and dispyramide. Heart Vessel 1995, 10, 7-11.

(13) Butwell, N. B.; Ramasamy, R.; Lazar, I.; Sherry, A. D.; Malloy, C. R. Effect of lidocaine on contracture, intracellular sodium and $\mathrm{pH}$ in ischemic rat hearts. Am. J. Physiol. 1993, 264, H1884-H1889.

(14) Tani, M.; Neely, J. R. Role of intracellular $\mathrm{Na}^{+}$in $\mathrm{Ca}^{2+}$ overload and depressed recovery of ventricular function of reperfused ischemic rat hearts. Possible involvement of $\mathrm{H}^{+}-\mathrm{Na}^{+}$exchange. Circ. Res. 1989, 65, 1045-1056.

(15) Pike, M. M.; Kitakaze, M.; Chacko, V. P.; Marban, E. Lidocaine prevents the increase in myocardial free calcium during ischemia and reperfusion: an antiarrhythmic mechanism. Circulation 1987, 76, IV16.

(16) Saint, D. A. The cardiac persistent sodium current: an appealing therapeutic target? Br. J. Pharmacol. 2008, 153, 1133-1142.

(17) Arakawa, J.; Hara, A.; Kokita, N. Lidocaine attenuates mechanical and metabolic derangements induced by palmitoyl-L-carnitine in the isolated perfused rat heart. Pharmacology 1997, 55, 259-268.

(18) Das, D. K.; Misra, H. P. Lidocaine: a hydroxyl radical scavenger and singlet oxygen quencher. Mol. Cell. Biochem. 1992, 115, 179-185.

(19) Josephson, I. R. Lidocaine blocks $\mathrm{Na}, \mathrm{Ca}$, and $\mathrm{K}$ currents of chick ventricular myocytes. J. Mol. Cell. Cardiol. 1988, 20, 593-604.

(20) Sugiyama, K.; Muteki, T. Local anesthetics depress the calcium current of rat sensory neurons in culture. Anesthesiology 1994, 80, 13691378.

(21) Kojima, M.; Miura, M. Protective effect of lidocaine on the ischemicreperfused rat heart: a phosphorus 31 nuclear magnetic resonance study. Basic Res. Cardiol. 1993, 28, 619-628.

(22) Ohmura, T.; Muramatsu, I.; Kigoshi, S.; Noguchi, H.; Muraoka, R.; Komoriya, Y.; Hayashi, H. Novel cardioprotective effects of TYB3823 on ischemic damage in the working hearts of rats: comparison with lidocaine. J. Pharmacol. Exp. Ther. 1990, 254, 696-701.

(23) Vitola, J. V.; Forman, M. B.; Holsinger, J. P.; Atkinson, J. B.; Murray, J. J. Reduction of myocardial infarct size in rabbits and inhibition of activation of rabbit and human neutrophils by lidocaine. Am. Heart J. 1997, 133, 315-322.

(24) Wendland, M. F.; Saeed, M.; Kondo, C.; Derugin, N.; Higgins, C. B. Effect of lidocaine on acute regional myocardial ischemia and reperfusion in the cat. An in-vivo 31P magnetic resonance spectroscopy study. Invest. Radiol. 1993, 28, 619-628.

(25) Hatori, N.; Roberts, R. L.; Tadokoro, H.; et al. Differences in infarct size with lidocaine as compared with bretylium tosylate in acute myocardial ischemia and reperfusion in pigs. J. Cardiovasc. Pharmacol. 1991, 18, 581-588.

(26) Lee, R.; Nitta, T.; Schmid, R. A.; Schuessler, R. B.; Harris, K. M.; Gay, W. A. Retrograde infusion of lidocaine or L-arginine before reperfusion reduces myocardial infarct size. Ann. Thorac. Surg. 1998, $65,1353-1359$.

(27) Lesnefsky, E. J.; Van Benthuysen, K. M.; McMurtry, I. F.; Shikes, R. H.; Johnston, R. B.; Horwitz, L. D. Lidocaine reduces canine infarct size and decreases release of a lipid peroxidation product. J. Cardiovasc. Pharmacol. 1989, 13, 895-901.

(28) Koufaki, M.; Calogeropoulou, T.; Rekka, E.; Chryselis, M.; Papazafiri, P.; Gaitanaki, C.; Makriyannis, A. Bifunctional Agents for Reperfusion Arrhythmias: Novel Hybrid Vitamin E/Class I Antiarrhythmics. Bioorg. Med. Chem. 2003, 11, 5209-5219.

(29) Koufaki, M.; Kiziridi, C.; Papazafiri, P.; Vassilopoulos, A.; Varró, A.; Nagy, Z.; Farkas, A.; Makriyannis, A. Synthesis and biological evaluation of benzopyran analogues bearing class III antiarrhythmic pharmacophores. Bioorg. Med. Chem. 2006, 14, 6666-6678. 
(30) Zhang, W. H.; Chan, W. L.; Lin, Y. H.; Szeto, Y. S.; Lin, Y. C.; Yeung, C. H. Synthesis of hydroxyflavanones from substituted acetophenones and benzaldehydes in the presence of silica gel, boric acid and piperidine. Heterocycles 1997, 45, 71-75.

(31) Kano, S.; Tanaka, Y.; Sugino, E.; Hibino, S. Reduction of some functional groups with titanium(IV) chloride/sodium borohydride. Synthesis 1980, 695-697.

(32) Phillips, G. B.; Morgan, T. K.; Nickish, K.; Lind, J. M.; Gomez, R. P.; Wohl, R. A.; Argentieri, T. M.; Sullivan, M. E. Synthesis and cardiac electrophysiological activity of aryl-substituted derivatives of the class III antiarrhythmic agent sematilide. J. Med. Chem. 1990, 33, 627633.

(33) Ouertani, M.; Girard, P.; Kagan, H. B. Selective Nitration of Phenols Catalyzed by Lanthanum(III) Nitrate. Tetrahedron Lett. 1982, 23, 4315-4318.

(34) Ono, A.; Hiroi, M.; Shimazaki, K.; Reduction of aromatic nitrocompounds by the sodium borohydride-copper(I) chloride system.; Chem. Ind. 1984, 75.

(35) Malen, C.; Lacoste, J.-M.; Vilaine, J.-P.; Lenaers, A. Acylaminophenol compounds. U.S. Patent 5254590, 1993.

(36) Mortensen, D. S.; Rodriguez, A. L.; Carlson, K. E.; Sun, J.; Katzenellenbogen, B. S.; Katzenellenbogen, J. A. Synthesis and biological evaluation of a novel series of furans: ligands selective for estrogen receptor alpha. J. Med. Chem. 2001, 44, 3838-3848.

(37) Cava, M. P.; Leninsson, M. I. Thionation Reactions of Lawesson Reagents. Tetrahedron 1985, 41, 5061-5087.

(38) Lepore, S. D.; He, Y. Use of Sonication for the Coupling of Sterically Hindered Substrates in the Phenolic Mitsunobu Reaction. J. Org. Chem. 2003, 68, 8261-8263.

(39) Caron, S.; Vasquez, E. Efficient Synthesis of [6-Chloro-2-(4-chlorobenzoyl)- $1 H$-indol-3-yl]-acetic Acid, a Novel COX-2 Inhibitor. $J$. Org. Chem. 2003, 68, 4104-4107.

(40) Heisler, B. E.; Ferrier, G. Proarrhythmic actions of flecainide in an isolated tissue model of ischemia and reperfusion. J. Pharmacol. Exp. Ther. 1996, 279, 317-324.

(41) Walker, M.; Curtis, M.; Hearse, D. The Lambeth Conventions: guidelines of the study of arrhythmias in ischemia, infarction, and reperfusion. Cardiol. Res. 1988, 22, 447-455.

(42) (a) Ceconi, C.; Cargnoni, A.; Pasini, E.; Condorelli, E.; Curello, S. Ferrari, R. Evaluation of phospholipid peroxidation as malondialdehyde during myocardial ischemia and reperfusion injury. Am. J. Physiol. Heart Circ. Physiol. 1991, 260, H1057-H1061. (b) Lefer, D. J.; Granger, N. Oxidative Stress and Cardiac Disease. Am. J. Med. 2000, 109, 315-323.

(43) Draper, H. H.; Hardley, M. Malondialdehyde Determination as Index of Lipid Peroxidation. Methods Enzymol. 1990, 186, 283-293.

(44) Lathrop, D. A.; Varró, A.; Nánási, P. P.; Bódi, I. I.; Takyi, E.; Pankucsi, C. Differences in the Effects of D- and DL-Sotalol on Isolated Human Ventricular Muscle: Electromechanical Activity after Beta-Adrenoreceptor Stimulation. J. Cardiovasc. Pharmacol. Ther. 1996, 1, 6574.

(45) (a) Varro, A.; Elharrar, V.; Surawicz, B. Frequency-dependent effects of several class I antiarrhythmic drugs on $V_{\max }$ of action potential upstroke in canine cardiac Purkinje fibers. J. Cardiovasc. Pharmacol. 1985, 7, 482-492. (b) Varró, A.; Lathrop, D. A. Sotalol and mexiletine: combination of rate-dependent electrophysiological effects. J. Car- diovasc. Pharmacol. 1990, 16, 557-567. (c) Mátyus, P.; Varga, I.; Rettegi, T.; Simay, A.; Kállay, N.; Károlyházy, L.; Kocsis, A.; Varró, A.; Pénzes, I.; Papp, J. G. Novel antiarrhythmic compounds with combined class IB and class III mode of action. Curr. Med. Chem. 2004, 11, 61-69.

(46) Campbell, T. J.; Vaughan Williams, E. M. Voltage- and time-dependent depression of maximum rate of depolarisation of guinea-pig ventricular action potentials by two new antiarrhythmic drugs, flecainide and lorcainide. Cardiovasc. Res. 1983, 17, 251-258.

(47) Campbell, T. J. Kinetics of onset of rate-dependent effects of class I antiarrhythmic drugs are important in determining their effects on refractoriness in guinea-pig ventricle and provide a theoretical basis for their subclassification. Cardiovasc. Res. 1983, 17, 344-352.

(48) Knilans, T. K.; Lathrop, D. A.; Nánási, P. P.; Schwartz, A.; Varró, A. Rate and concentration-dependent effects of UK-68,798, a potent new class III antiarrhythmic, on canine Purkinje fibre action potential duration and $V_{\max }$. Br. J. Pharmacol. 1991, 103, 1568-1572.

(49) Papp, J. G.; Németh, M.; Krassói, I. I.; Mester, L.; Hála, O.; Varró, A. Differential Electrophysiologic Effects of Chronically Administered Amiodarone on Canine Purkinje Fibers versus Ventricular Muscle. J. Cardiovasc. Pharmacol. Ther. 1996, 1, 287-296.

(50) Gerebtzoff, G.; Li-Blatter, X.; Fischer, H.; Frentzel, A.; Seelig, A. Halogenation of Drugs Enhances Membrane Binding and Permeation. ChemBioChem 2004, 5, 676-684.

(51) (a) Achari, B.; Mandal, S. B.; Dutta, P. K.; Chowdhurry, C. Perspectives on 1,4-benzoxazines and their 2,3-dihydro derivatives. Synlett 2004, 2449-2467. (b) Cecchetti, V.; Tabarrini, O.; Sabatini, S. From Cromakalim to Different Structural Classes of $K_{\text {ATP }}$ Channel Openers. Curr. Top. Med. Chem. 2006, 6, 1049-1068.

(52) Ilaš, J.; Anderluh, P.; Dolenc, M. S.; Kikelj, D. Recent advances in the synthesis of $2 \mathrm{H}$-1,4-benzoxazin-3-(4H)-ones and 3,4-dihydro- $2 \mathrm{H}$ 1,4-benzoxazines. Tetrahedron 2005, 61, 7325-7348.

(53) Rybczynski, P. J.; Zeck, R. E.; Dudash, J.; Combs, D. W.; Burris, T. P.; Yang, M.; Osborne, M. C.; Chen, X.; Demarest, K. T. Benzoxazinones as PPAR $\alpha$ Agonists. 2. SAR of the Amide Substituent and In Vivo Results in a Type 2 Diabetes Model. J. Med. Chem. 2004, 47, 196-209.

(54) The corresponding compounds were detected by GC-MS but decomposed upon isolation.

(55) (a) Pratt, C. M.; Camm, A. J.; Cooper, W.; Friedman, P. L.; MacNeil, D. J.; Moulton, K. M.; Pitt, B.; Schwartz, P. J.; Veltri, E. P.; Waldo, A. L. Mortality in the Survival With Oral D-sotalol (SWORD) trial: why did patients die? Am. J. Cardiol. 1998, 81, 869-876. (b) Waldo, A. L.; Camm, A. J.; deRuyter, H.; Friedman, P. L.; MacNeil, D. J.; Pauls, J. F.; Pitt, B.; Pratt, C. M.; Schwartz, P. J.; Veltri, E. P. Effect of D-sotalol on mortality in patients with left ventricular dysfunction after recent and remote myocardial infarction. The SWORD Investigators Survival With Oral D-Sotalol. Lancet 1996, 348, 7-12. (c) Waldo, A. L.; Camm, A. J.; deRuyter, H.; Freidman, P. L.; MacNeil, D. J.; Pitt, B.; Pratt, C. M.; Rodda, B. E.; Schwartz, P. J. Survival with oral D-sotalol in patients with left ventricular dysfunction after myocardial infarction: rationale, design, and methods (the SWORD trial). Am. J. Cardiol. 1995, 75, 1023-1027.

JM801228H 